\title{
REGULARIZAÇÃO FUNDIÁRIA DE OCUPAÇÃO EM ÁREAS AMBIENTAIS E TUTELA JUDICIAL NO NOVO CÓDIGO DE PROCESSO CIVIL
}

\section{REGULARIZATION OF OCCUPATIONAL ENVIRONMENTAL OCCUPANCY AND JUDICIAL PROTECTION IN THE NEW CIVIL PROCESS CODE}

\author{
Emerson Affonso da Costa Moura ${ }^{1}$ \\ Mauricio Mota ${ }^{2}$
}

\section{Resumo}

A dificuldade do reconhecimento da regularização fundiária de ocupação em áreas ambientais, em razão da tensão da promoção do direito social à moradia à luz do meio ambiente ecologicamente equilibrado é o tema posto em debate. Verifica-se em que medida o novo código de processo civil traduz instrumentos que permitem mediante o controle social ao reconhecimento e proteção efetiva da posse nas respectivas áreas.

Palavras-chaves: Ocupação; área ambiental; Regularização fundiária; Controle Judicial; Código de Processo Civil.

\begin{abstract}
The difficulty of recognizing land tenure regularization in environmental areas due to the tension of promoting the social right to housing in the light of the ecologically balanced environment is the subject of debate. We can see to what extent the new civil process code translates instruments that allow, through social control, the recognition and effective protection of tenure in the respective areas.
\end{abstract}

Keywords: Occupation; environmental area; Land regularization; Judicial Control; Code of Civil Procedure.

\footnotetext{
${ }^{1}$ Professor Adjunto da Universidade Federal Rural do Rio de Janeiro (UFRRJ). Doutor em Direito pela Universidade do Estado do Rio de Janeiro (UERJ). Pesquisador certificado pelo CNPQ pela Universidade Federal Fluminense (UFF).E-mail: emersonacmoura@yahoo.com.br

2 Doutor em Direito e Professor Adjunto da Universidade do Estado do Rio de Janeiro. E-mail: mjmota1@gmail.com
} 


\section{INTRODUÇÃO}

No Estado Liberal de Direito erige-se a propriedade privada como um direito fundamental individual que concede um complexo de posições capaz de impor deveres de abstenção aos particulares e ao próprio Estado, que não interfiram à satisfação dos interesses próprios de seu titular definidos a partir de sua autonomia privada.

Sob tal concepção estrita de direito de propriedade associada à proteção da liberdade de iniciativa permitiu-se o amplo desenvolvimento da atividade econômica privada, porém, igual déficit humano e social, que aliado a demais fatores, representou o declínio do modelo de Estado Liberal e a necessidade de ascensão de um modelo voltado à garantia dos fins coletivos.

No Brasil, agrava-se a questão já que desde a colonização, a ocupação do solo brasileiro foi marcada pela exploração econômica e a política excludente de forma que o acesso formal a terra era restrito aqueles que detivessem o capital, gerando a mercantilização da propriedade privada com os seus efeitos perniciosos, de ocupação irregular do solo urbano.

Com avançar da industrialização e crescimento dos centros urbanos nacionais, agravam-se os problemas urbanos de violência e desemprego, de inundações e deslizamentos, de falta de equipamentos urbanos e inchaço da demanda por serviços públicos, trazendo a lume a questão do acesso precário à moradia e a necessidade de políticas habitacionais.

Antes centrada na remoção das populações das favelas, com a construção de conjuntos habitacionais para as famílias carentes e o oferecimento de acesso ao financiamento imobiliária para a classe média, observa-se em fins do século passado, movimento para ampliação do conceito de direito à moradia, ligando não apenas a propriedade, mas identidade do indivíduo.

Todavia, é inegável que a ocupação de terras em áreas ambientais traduzem em um novo desafio à regulação estatal já que colocam na regularização fundiária o conflito entre a proteção da posse funcionalizada à moradia com a proteção com região de preservação para o meio ambiente ecologicamente equilibrado.

Busca o presente trabalho analisar as contribuições do novo Código de Processo Civil no que tange ao controle judicial da regularização fundiária de áreas ambientais forma a garantir a 
proteção do direito humano fundamental social à moradia em que pese seu conflito com o meio ambiente ecologicamente equilibrado.

Para tanto, analisa-se a histórica ocupação irregular do solo brasileiro e a tentativa de correção mediante políticas públicas de habitação para após verificar-se como isto resultou em um problema de moradia no Brasil que conduz a necessidade de regulação fundiária.

Ato contínuo, problematiza-se como isto gera uma tensão no que se refere aos bens ambientais, para então sustentar em que medida, a proteção da ocupação ocorrerá pela tutela judicial e encontrará no novo código de processo civil instrumentos que permitam a proteção do direito à moradia.

\section{OCUPAÇÃO IRREGULAR DO SOLO BRASILEIRO E AS POLÍTICAS PÚBLICAS DE HABITAÇÃO}

No Brasil o fenômeno urbano encontra precedente na política de ocupação e povoamento da Colônia e sua evolução se liga aos ciclos econômicos brasileiros, de forma que mesmo no Império quando o processo de urbanização deixou de ser limitado às áreas litorâneas onde ocorria a exploração de recursos naturais como o pau-brasil, o fenômeno de interiorização foi orientado com a criação de cidades e vilas com fins de produção do café ${ }^{3}$. Por efeito, a formação e evolução das cidades brasileiras antes resultam, portanto, da ação das autoridades estatais do que fruto da própria sociedade:

Em nosso povo, a organização política dos núcleos locais, feitoria ou arraial não é posterior ou mesmo concomitante à sua organziação social. É-lhes anterior. Nasce-lhes a população já debaixo das prescrições administrativas. É o caso de São Vicente e Santo André da Borda do Campo. Funda-os Martim Afonso da Silva, logo ao lançar os germens da primeira colonização ao sul. Neles constrói, desde o seu início, o pelourinho, a igreja, a alfândega, todos os elementos essenciais da aparelhagem administrativa. VIANNA, Oliveira. Populações Meridionais do Brasil. Brasília: Senado Federal, 2005. p. 331.

Embora os centros urbanos tenham sido responsáveis pela ligação do campo - tal qual local eminente da atividade produtiva - com o comércio internacional - exímia fonte de recursos e financiamento - e, portanto, exerceu papel central na articulação da economia externa - tal fenômeno conferiu para as cidades além de certa autonomia e concentração das

\footnotetext{
${ }^{3}$ SILVA, José Afonso da. Direito Urbanístico Brasileiro. 7 ed. São Paulo: Malheiros, 2012. p. 21.
} 
atividades administrativas, um descolamento dos poucos e desconexos núcleos urbanos com baixa taxa de moradia em relação ao espaço de maior núcleo habitacional que era o campo ${ }^{4}$.

Ademais, o próprio processo de formação da cidade brasileira no período colonial, que ao revés de seguir a diretiva a colonização espanhola na América - cujo traçado urbano marcada pelo acento retilíneo demonstrava a tentativa de conformar a paisagem natural aos fins de extensão do domínio castelhano tal como nas colônias romanas - a ocupação lusitana teve como ponto nodal o mal aparelhamento, a liberalidade e a predominância dos fins econômicos que importou na construção de cidades eminentemente litorâneas e a criação da figura no coletivo social do "interior" enquanto local pouco povoado e não urbanizado, distanciada de qualquer preocupação relativa quanto a sua formação. Nas lições de Sérgio Buarque de Holanda 5 :

A cidade que os portugueses construíram na América não é produto mental, não chega a contradizer o quadro da natureza, e sua silhueta não se enlança na linha da paisagem. Nenhum rigor, nenhum método, nenhuma providência, sempre esse significativo abandono que exprime a palavra "desleixo" (HOLANDA, Sérgio Buarque de. As Raízes do Brasil. São Paulo: Companhia das Letras,. 1995. p. 110).

Observa-se, portanto, que a política urbana adotada no Brasil não foi de seguir extritamente os planos urbanísticos de Portugual - com desenhos em xadrez orientados no sentido norte-sul e leste-oeste - mas garantir tão somente a função econômica da rede urbana - de ocupação temporária com fins de armazenamento e exportação dos produtos brasileiros e de importação e comercialização dos produtos europeus - o local de assentamento das cidades - em sítio elevados em razão do caráter defensivo dos primeiros núcleos o que dificultava o arruamento em xadrez - e a própria concepção ideológica lusitana de não afirmar suas altas qualidades culturais perantes povos submetidos. ${ }^{6}$

Por efeito, enquanto o espaço rural era marcado pela quase auto-suficiência, os núcleos urbanos já denotavam mazelas sociais - como a miséria e a dificuldade de escoamento de produção - e legados políticos - com a administração urbana sujeita ao poder local e a figura dos "homens bons" em ofuscada distinção entre o domínio do público e do privado, da sociedade patriarcal e da administração patrimonialista, do campo e da cidade ${ }^{7}$ de onde se ensaiou nas primeiras etapas da colonização um quadro de dependência econômico e político

\footnotetext{
${ }^{4}$ MARICATO, Erminia. Habitação e Cidade. 6 ed. São Paulo: Atual, 1997. p. 8.

${ }^{5}$ HOLANDA, Sérgio Buarque de. Op. cit. p. 96-98 e 107-108.

6 VIANNA JÚNIOR, Hélio. A Estrutura Interna da Cidade in: KACOWICZ, Mateus. Desenvolvimento e Política Urbana. Rio de Janeiro: IBAM, 1976. p. 96-97.

${ }^{7}$ MARICATO, Erminia. Habitação... Op. cit. p. 10.
} 
das cidades aos domínio agrário, sendo os arraias, as vilas e as cidades não a oposição, mas partes integrantes dos clãs feudatários rurais. ${ }^{8}$

Sob a vigência de tal ordem, as áreas rurais eram locais eminentemente de habitação afluindo a população aos centros urbanos apenas para questões administrativas, de festejos ou solenidades. A ocupação com fins de moradia das cidades ocorria em sua maior parte apenas por parte de funcionários da administração, oficiais mecânicos e mercadores em geral, sendo marcada pelo descuido da residência urbana em razão da proeminência da moradia rural, além da miséria urbana como retrato da constante ausência de habitantes. ${ }^{9}$

Tal universalidade do fenômeno urbano brasileiro no período apenas é contrastada com a singularidade da dominação holandesa. Como ponto fora da curva do fenômeno ruralista brasileiro, o processo de urbanização sob o domínio de Nassau resultou em amplo processo de migração do campo para a cidade que resultou em uma vida urbana anormal e prematura marcada pela escassez notável de habitações para abrigo de novos moradores e moradia improvisada e insuficiente ${ }^{10}$. Sob tais vértices, denota-se a origem histórica das duas matrizes da problemática fundiária nas cidades brasileiras persistentes na contemporaneidade: a ampla taxa de desocupação dos imóveis urbanos e a ocupação irregular do solo urbano.

Tais mazelas, não são alteradas com a mudança do ciclo econômico no século XVIII com o declínio da produção do açúcar, a ascensão da exploração do ouro e a expansão da pecuária - e o movimento de interiorização que forjou a formação de vilas e pequenas cidades, inclusive, algumas com manifestações artísticas e culturais, bem como, a fixação de normas para ocupação do solo nos territórios de domínio português com as Ordenações Filipinas e a política de urbanização de Pombal que apesar de resultar nas grandes cidades na realização de obras públicas não foi capaz de superar a desordem na moradia urbana e a escassez habitacional nas cidades. ${ }^{11}$

Permaneceram certas características dos ciclos econômicos anteriores como a alta taxa de desocupação urbana. Se no ciclo da cana-de-açúcar a ocupação das residências urbanas pelos dos de engenho ocorrria na época da comercialização e embarque do produto, com o ciclo do café, o fazendeiro assume papel de empresário comercial e a residência urbana tem

\footnotetext{
${ }^{8}$ VIANNA, Oliveira. Op. cit. p. 341.

${ }^{9}$ HOLANDA, Sérgio Buarque de. Op. cit. p. 90-91.

10 HOLANDA, Sérgio Buarque de. Op. cit. p. 92.

11 MARICATO, Erminia. Habitação... Op. cit. p. 12-15.
} 
caráter de permanência bem maior, fixando uma população urbana mais numerosa e com maior poder aquisitivo. ${ }^{12}$

Neste giro, inegável que a transferência da Corte Portuguesa para o Brasil e a elevação do Brasil à categoria de Reino Unido produziu impacto no processo de urbanização, em especial, da cidade do Rio de Janeiro. Para acomodação da família real e do corpo burocrático na cidade houve a desocupação das principais edificações. Com a corte a vida cultural ampliouse a população carioca e o ambiente cultural como com a construção do Teatro Municipal, da Biblioteca nacional e a Academia de Belas Artes, dotando de maior vida e garantindo maior diversidade na cidade. ${ }^{13}$

Porém, é apenas no final do século XIX que sob o influxo da abolição da escravidão e do processo de industrialização ampliou-se o fluxo migratório do campo e o crescimento da ocupação habitacional da cidade em um contraste com a feição de mercadoria privada assumida pela terra enquanto instrumento de produção de bens e de riqueza: da concessão de sesmarias com as cartas de foral de 1520 até a sua suspensão por José Bonifácio em 1822 e a consequente ocupação ampla e indiscriminada, consolidou-se na realidade fundiária brasileira o latifúndio como modelo excludente de acesso à propriedade. ${ }^{14}$

Sob tal influência econômica que se firmaram as malhas urbanas no eixo CentroSudeste em razão da mineração ou da cana-de-açúcar no Nordeste e no Sul, de modo que mesmo a construção de Brasília com a mudança da Capital no Interior tendo atraído a urbanização ao interior não foi capaz de superar a concentração industrial e, portanto, do fenômeno urbano no eixo São Paulo, Minas Gerais e Rio de Janeiro ${ }^{15}$. Em decorrência, junto ao intenso crescimento econômico houve a ampliação daquelas mazelas - a desigualdade social e a pobreza-também em nível espacial ${ }^{16}$.

Com o surgimento da classe de trabalhadores industriais e a chegada dos escravos libertos aos núcleos urbanos houve o crescimento desordenado das cidades acarretando demanda por moradia, transporte e serviços urbanos, todas as mazelas decorrentes de concentração da pobreza, ausência de saneamento básico, altos índices de desemprego e

\footnotetext{
12 VIANNA JUNIOR, Helio. A Estrutura Interna da Cidade. p. 99-100.

${ }^{13}$ MARICATO, Erminia. Habitação... Op. cit. p. 16.

${ }^{14}$ MARICATO, Erminia. Habitação... Op. cit. p. 22-23.

15 SILVA, José Afonso da. Op. Cit. p. 22.

${ }^{16}$ MARICATO, Ermínia. Metrópole na Periferia do Capitalismo. Op. Cit. p. 55.
} 
criminalidade, insalubridade e epidemias, bem como, o congestionamento habitacional nos cortiços e casas de cômodo. ${ }^{17}$

Diante da força política dos poderes locais capaz de resistir a tentativa estatal de demarcação das terras devolutas e da criminalização do acesso à terra pela ocupação pura e simples pela edição da Lei de $\operatorname{Terras}^{18}{ }^{18}$ o problema fundiário persistiu ainda mesmo com a regulação pela lei civil do acesso à propriedade imóvel privada ${ }^{19}$, com a permanência de um modelo de aquisição da propriedade excludente, ocupação irregular da terra urbana e os consequentes efeitos funestos à Cidade.

O próprio fundamento da Lei de Terras foi assegurar no plano jurídico a nova relação imposta pelo modo de produção para impedir no momento de ascensão do modelo capitalista o acesso do trabalhador à terra, pois submetia a aquisição das terras devolutas à compra e venda, o que significava destinar a sua ocupação aquele que tivesse condições financeiras para arcar e, portanto, garantir que a massa antes oferecesse seu trabalho do que tivesse condição de fazer-se proprietário e ter acesso aos meios de produção. ${ }^{20}$

Neste tocante, os programas urbanísticos brasileiros persistiram ligados aos ciclos econômicos, de modo que as reformas urbanas eram as medidas capazes de garantir a expansão da economia e a atração de capitais internos, que demandava na cidade do Rio de Janeiro a ampliação da capacidade do porto, de armazenamento de produtos e mercadorias, bem como, do sistema viário destinado à circulação dos produtos resultou em um conjunto de políticas públicas nas primeiras décadas do século XX. ${ }^{21}$

Porém, encontrava tal limitação ocupação irregular da terra urbana o que demandou complexas legislações para a edificação e código de posturas municipais que buscavam conter a proliferação de cortiços e a prática de autoconstrução da moradia, em especial, das favelas inicialmente instaladas nos morros mais próximos ao centro das cidades. Surgem intervenções estatais tinham natureza excludente como o despejo de famílias pobres dos conhecidos edifícios multihabitacionais conhecidos como cortiços ou "cabeças-de-porco" nas áreas centrais da cidade carioca. ${ }^{22}$

\footnotetext{
17 MARICATO, Erminia. Habitação... Op. cit. p. 27.

18 BRASIL, Lei no 601 de 18 de Setembro de 1850.

19 BRASIL, Lei no 3.071 de 1 de Janeiro de 1916. Art. 530.

20 BALDEZ, Miguel Lanzellotti. Solo urbano: Propostas para a Constituinte. Rio de Janeiro: Apoio Juridico Popular, 1986. p. 56.

${ }^{21}$ MARICATO, Erminia. Habitação... Op. cit. p. 28.

22 MARICATO, Erminia. Habitação... Op. cit. p. 28 e 30.
} 
Ainda diante do inconformismo popular com tais medidas que resultou na Revolta da Vacina, a reforma urbana "regeneração" do Rio de Janeiro sob a influência da reforma de Paris do Barão de Haussmann no governo Napoleônico de 1850 e 1870 foi acompanhada por outras cidades sob o tripé saneamento - de afastamento de setores marginalizados como miseráveis, mendigos e negros das áreas centrais - embelezamento - tratamento estético e paisagístico que pressupunha a inexistência da pobreza e - segregação territorial - com a resolução do problema fundiário com a alocação da massa trabalhadora pobre para moradia em áreas afastadas. ${ }^{23}$

Consolidou-se, portanto, um modelo de modernização excludente que persiste no século XX, marcado pela segregação e diferenciação na ocupação do solo urbano e na distribuição dos equipamentos públicos entre a cidade hegemônica ou oficial - garantindo benefício para os proprietários da terra e nascente capital imobiliário - e a cidade oculta ou inoficial - carente de serviços de infra-estrutura, excetuado a extensão do transporte coletivo e serviços essenciais que viabiliza o assentamento residencial da população trabalhadora pobre no subúrbio ${ }^{24}$ :

"Se na cidade imperial os escravos viviam junto a seus proprietários, a
cidade da República separa o trabalho do ócio. Explusa os negros e
brancos pobres para as periferias, para os subúrbios, para os morros ou
para as várzas. Os edifícios, lojas e serviços na cidade republicana
escondem o trabalho das cozinhas, das oficinas. A cidade oculta o
trabalho e segrega o trabalhador". (MARICATO, Erminia. Habitação... Op.
cit. p. 28).

Sob a égide de um modelo econômica excludente, a ocupação do solo urbano para fins de habitação acabou sendo reforçado por parte da população de forma irregular mediante o loteamento ilegal ou a autoconstrução parcelada que resultou em amplas periferias, por exemplo, no Rio de Janeiro ${ }^{25}$. As tentativas de superação da realidade fundiária urbana mediante intervenção do Estado ocorreram através da criação de incentivo público para que a iniciativa privada produzisse habitação popular. ${ }^{26}$

Todavia, o baixo poder aquisitivo da população e a concorrência da informalidade resultaram em investimento pelas grandes sociedades em parcelamento de solo e comercialização de lotes enquanto o pequeno empresariado investiu na produção de pequenos núcleos - como vilas e condomínios de casa - destinada à locação. Sob um vértice gerou altas

\footnotetext{
${ }^{23}$ MARICATO, Erminia. Habitação... Op. cit. p. 29.

${ }^{24}$ MARICATO, Erminia. Habitação... Op. cit. p. 30.

25 SILVA, José Afonso da. Op. Cit. p. 23.

${ }^{26}$ MARICATO, Ermínia. Habitação... Op. cit. p. 33.
} 
taxas de crescimento domiciliar, em outro o aumento dos aluguéis e os baixos salários dos trabalhadores que conduziu a movimentos sociais dos locatários e greve dos inquilinos intervindo o Estado com a aprovação de decreto regulando a locação dos prédios urbanos ${ }^{27}$, além da ampliação da regulação sobre o uso do solo e construção das edificações que resulta na edificação de escritórios e apartamentos como forma de moradia. ${ }^{28}$

Apenas a partir da década de 1930 que se iniciou o processo efetivo de urbanização com a previsão de uma política social de habitação que resultou no financiamento pelo Estado da construção de moradias, porém, sendo a maior parte destinada a aluguel, bem como, na criação dos parques proletários destinados à transferência de favelados, que também, não produziu mudança nas condições de moradia. Intervenções estatais como o congelamento dos aluguéis $^{29}$ gerou em longo prazo o desestímulo às ofertas de moradia e a Fundação da Casa Popular ${ }^{30}$ foi capaz de financiar apenas poucas moradias. ${ }^{31}$

O loteamento irregular na periferia, a ocupação ilegal de terras e a autoconstrução de moradias foi a solução adotada pela massa trabalhadora em reforço ao modelo excludente. Com a ampliação da industrialização a partir da década de 50 no século XX incorporou-se de vez ao crescimento urbano do ideário urbanístico modernista em uma utopia construída por arquitetos de organização da cidade conforme suas funções através das leis de zoneamento amplamente descolada da realidade ${ }^{32}$ :

(...) consolidando nas décadas seguintes um conjunto de "idéias fora do lugar": enquanto nos gabinetes governamentais uma realidade virtual era "organizada" no papel e nos textos das leis, a concretude revelava que grande parte da população, os excluídos do mercado imobiliário privado, ocupava o solo ilegalmente, construindo sua própria casa com seus parcos recursos técnicos e financeiros". (MARICATO, Ermínia. Habitação... Op. cit. p. 39).

Neste contexto, o tratamento de qualquer problemática urbana pautou-se pela abordagem não sistematizada e casuística de aspectos locais na organização espacial intraurbana e a remoção de estrangulamentos na infra-estrutura social básica mediante soluções setoriais isoladas, inclusive, como na habitação. As tentativas de coordenação de política nacional não foram capazes de estabelecer linhas de uma ação urbana integrada. Os

\footnotetext{
27 BRASIL, Decreto no 4.403, de 22 de Dezembro de 1921.

28 MARICATO, Ermínia. Habitação... Op. cit. p. 35.

${ }^{29}$ BRASIL, Decreto-Lei no 4.598, de 20 de Agosto de 1942.

30 BRASIL, Decreto-Lei no 9.777, de 6 de Setembro de 1946.

31 MARICATO, Ermínia. Habitação... Op. cit. p. 37.

32 MARICATO, Ermínia. Habitação... Op. cit. p. 37 e 39.
} 
instrumentos de programação global de investimentos não conseguiu especificar uma função de desenvolvimento urbano. ${ }^{33}$

Houve a edição de lei federal que dentre outras políticas habitacionais instituiu ao lado do regime de loteamento destinado à venda mediante pagamento do preço em prestações, um regime de urbanificação que previa a construção e casas populares com fins de garantir a eliminação de favelas, mocambos e outras aglomerações em condições subhumanas de habitação, além de prever ofertas de terrenos já urbanizados e projetos da sociedade civil ou da iniciativa privada para auxiliar solver os problemas habitacionais. ${ }^{34}$ Porém, tal regime jurídico não foi suficiente para garantir a tutela plena do direito à moradia.

O Sistema Financeiro da Habitação e o Banco Nacional da Habitação embora tenham promovido uma profunda transformação no espaço urbano brasileiro não gerou ruptura com sistema anterior: a ideologia da casa própria se tornou absoluta, o mercado de produção de habitação de várias unidades se ampliou para atender a classe média e o crescimento do sistema viário aberto ocorreu para a circulação de imóveis. Isto, todavia, apenas aprofundou a segregação espacial e a exclusão social e agravou o problema de moradia. ${ }^{35}$

Com a edição da lei nacional disciplinadora do parcelamento do solo urbano ${ }^{36}$ e as vedações legais impostas ao parcelamento em dados terrenos em razão de sua condição geológica ou em áreas de preservação ecológica, os requisitos urbanísticos do solo urbano como área mínima, exigência de planta do imóvel, projeto contendo desenhos, memorial descritivo e cronograma de execução das obras de parcelamento, bem como, os demais relativos a desmembramento ignorando a realidade fática social e econômica subjacente dos habitantes apenas se agravou o crescimento da ocupação de áreas de preservação ambiental, reforçando o processo de ocupação excludente e segregadora do solo urbano ${ }^{37}$.

As sucessivas tentativas de regulamentação do uso da terra - com códigos de edificação, leis de noeamento, normas para o parcelamento do solo - apresentaram-se como virtualmente fracassadas no Brasil, tal qual ocorreu em países menos desenvolvidos em razão da falta de fiscalização capaz de fazer prevalecer às restrições e sua utilização não para a

\footnotetext{
33 BARAT, Josef. Problemas Institucionais do Planejamento Urbano. in: KACOWICZ, Mateus. Op. cit. p. $128 / 136$

${ }^{34}$ BRASIL, Lei no 4.380 de 19 de Agosto de 1964. Art. 4ㅇ․

${ }^{35}$ MARICATO, Ermínia. Habitação... Op. cit. p. 48.

${ }^{36}$ BRASIL, Lei no 6.766 de 19 de Dezembro de 1979.

37 MARICATO, Ermínia. Metrópole na Periferia do Capitalismo: Ilegalidade, Desigualdade E Violência. São Paulo: Editora Hucitec, 1996. p. 47.
} 
melhoria das condições de vida da cidade, mas para a exclusão da comunidade carente das áreas de interesse do mercado. ${ }^{38}$

No que tange ao acesso à moradia por parcela do grupo social que mais sofre com os efeitos da desigualdade econômica, não se ignora que já existia previsão na normatização específica da desapropriação por interesse social da sua incidência para fins de construção de casas populares ${ }^{39}$. Todavia, isto não foi suficiente para resolver os problemas sociais de habitação, uma vez que a questão urbanística envolvia na época, bem como, na contemporaneidade a efetiva concretização do direito à moradia de parcela do grupo social incapaz diante de sua condição econômica de se inserir naquele sistema. ${ }^{40}$

Em sentido contrário, aos organismos internacionais que já apontavam na mesma quadra histórica a necessidade de se garantir a consagração do direito à moradia, ainda, que em conceito restritivo como apenas a habitação ${ }^{41}$ ou o alojamento suficiente ${ }^{42}$ apenas nas últimas décadas do século XX quando o processo de urbanização excludente agrava a questão habitacional nas metrópoles brasileiras pela ampliação da ocupação irregular em áreas onde inexistem ou são precárias a prestação dos serviços públicos e seus efeitos perniciosos como a explosão da violência urbana ${ }^{43}$ que o Estado Brasileiro busca adotar medidas relativas de forma ampla na questão habitacional, porém, de forma inadequada:

"Tanto as autoridades governamentais ligadas à política de habitação quanto os representantes do capital imobiliário referem-se frequentemente à questão da gabitação em termos numéricos de déficits ou projeções de unidades isoladas a serem construídas. Essa forma simplista de tratar o tema ignora que a habitação urbana vai além dos números e das unidades. Ela deve estar conectada às redes de infraestrutura e ter o apoio dos serviços urbanos. Se na zona rural algumas dessas necessidades podem ser resonvildas individualmente, na cidade sua inexistência pode inviabilizar a função da moradia ou carretar danos sociais e ambientais, além de exigir sacrifício por parte dos moradores". (MARICATO, Ermínia. Habitação... Op. cit. p. 43).

Não se ignora que a cidade reflete espacialmente o tipo de relações políticas, econômicas e sociais existentes na sociedade é que o padrão de distribuição espacial da população nas áreas urbanas brasileiras acaba sendo orientada pelo sistema de estratificação

38 BRASILEIRO, Ana Maria. A Cidade: Aspectos Políticos in: KACOWICZ, Mateus. Desenvolvimento e Política Urbana. Rio de Janeiro: Instituto Brasileiro de Administração Municipal, 1976. p. 36.

${ }^{39}$ BRASIL, Lei no 4.132 de 10 de Setembro de 1962. Art. 2으.

40 SILVA, José Afonso da. Op. Cit. p. 379.

${ }^{41}$ Organização das Nações Unidas, Assembléia Geral, Declaração Universal dos Direitos Humanos, em 10 de dezembro de 1948. Art. 25 Inciso I.

42 Organização das Nações Unidas, Assembléia Geral, Pacto Internacional dos Direitos Econômicos, Sociais e Culturais em 16 de Dezembro de 1966. Art. 11 I.

${ }^{43}$ MARICATO, Ermínia. Metrópole na Periferia do Capitalismo. Op. Cit. p. 16. 
social e determinando uma ocupação do solo basicamente incorporando tais linhas de desigualdades sendo os estratos inferiores aqueles que são mais atingidos pela manifestação dos problemas. ${ }^{44}$

Todavia, a partir da década de 90 do século anteiror as áreas metropolitanas brasileiras refletiram mais nitidamente a desigualdade social através da segregação espacial - com a produção e apropriação desigual do espaço urbano - a ampliação dos excludentes - com crescimento da população de rua e do comércio informal - e a setorialidade dos investimentos estatais - nas áreas valorizadas pelo mercado imobiliário que reforça mazelas como a violência e o problema habitacional. ${ }^{45}$

No conflito do espaço urbano - entre usuários da cidade que demandam moradia, transporte, lazer dentre outros e a iniciativa privada que dotam a cidade como valor de uso - o acesso à moradia ligou-se gradativamente ao preço e, portanto, sua localização na cidade que varia conforme o acesso aos serviços coletivos, equipamentos e infraestrutura ${ }^{46}$. A habitação tornou-se mercadoria especial dotada de produção e distribuição complexa dependente de um ciclo que abrange do capital de financiamento à produção, que envolve a sua produção e distribuição de acordo com os investimentos públicos feitos na cidade. ${ }^{47}$

Isto demandava para solucionar a problemática da regularização fundiária uma política habitacional capaz de garantir a justa utilização do solo e o fornecimento de habitação condigna a todas as famílias como já ensaiava o 1o Seminário de Habitação e Reforma Urbana promovido pelo Instituto de Arquitetos do Brasil ${ }^{48}$ e a necessidade do cientista jurídico atentar sobre a importância da questão da metrópole e dos seus problemas sociais e econômicos, do assentamento humano no solo da cidade enquanto exercício das liberdades públicas e do direito à Terra como já apontava a doutrina nas últimas décadas do século XX. ${ }^{49}$

Diante da ausência de um regime jurídico capaz de solver os problemas das habitações irregulares diversos instrumentos foram propostos pela doutrina para garantir a regularização fundiária de áreas assentadas populações de baixa renda - como favelas, mocambos, palafitas e loteamentos irregulares - como o usucapião especial urbano de bens públicos, bem como, o

\footnotetext{
${ }^{44}$ BRASILEIRO, Ana Maria. Op. cit. p. 26/27.

45 MARICATO, Ermínia. Metrópole... Op. Cit. p. 53-54.

${ }^{46}$ MARICATO, Ermínia. Metrópole... Op. Cit. p. 43-44.

47 MARICATO, Ermínia. Metrópole... Op. Cit. p. 47-48.

48 BONDUKI. Nabil; KOURY, Ana Paula. Das Reformas de Base ao BNH: As Propostas do Seminário de Reforma Urbana. XII Encontro da Associação Nacional de Pós-Graduação e Pesquisa em Planejamento Urbano e Regional, 21 a 25 de Maio de 2007, Belém, Pará, Rio de Janeiro. p. 5.

${ }^{49}$ LIRA, Ricardo Pereira. Elementos de Direito Urbanístico. Rio de Janeiro: Renovar, 1997. p. 109.
} 
direito de superfície permitindo a propriedade separada da acessão, distinta do solo, como instrumento capaz de garantir que tal regularização fundiária impedisse as novas migrações de contingentes atraídos por essa política. ${ }^{50}$

Ainda que a previsão da função social da propriedade já se encontrase no ordenamento jurídico constitucional desde a Emenda Constitucional 01/1969 $9^{51}$ a inexistência de legislação infraconstitucional que conformasse seu conteúdo delineando uma política urbana ou a organização dos espaços utilizáveis não dotava de eficácia a norma constitucional ${ }^{52}$. Houve projeto de lei que buscou explicitar a função social da propriedade tendo por diretrizes garantir iguais oportunidades de acesso à propriedade urbana e moradia, a regularização fundiária das áreas ocupadas por população de baixa renda e distribuição equitativa dos benefícios e ônus decorrentes da urbanização, todavia, o mesmo foi retirado pelo Poder Executivo em 1995 sem deliberação ${ }^{53}$.

Tal projeto foi substituído por outra proposição ${ }^{54}$ que previa usucapião especial de imóvel urbano coletivo para fins de moradia, permitindo a aquisição imobiliária de área ubana de metragem superior a duzentos e cinquenta metros quadrados, ocupado por edificação precária e mediante a posse ininterrupta e sem oposição. Tal projeto foi apensado àquele que viria estabelecer em 2001 o Estatuto da Cidade ${ }^{55}$, que previu além deste a atribuição dos entes municipais para programa de construção de moradias embora a concessão de uso especial para fins de moradia tenha sido vetado pelo Poder Executivo. ${ }^{56}$

Antes houve a criação de um regime de urbanificações para construção de moradias de interesse social instituído através de lei nacional de 1999 que produziu alterações nas regras relativas ao parcelamento de solo urbano impondo infra-estrutura básica dos parcelamentos situados nas zonas habitacionais declaradas por lei como de interesse social ${ }^{57}$, bem como, determinou a hipótese de desapropriação na modalidade de utilidade pública com fins de

\footnotetext{
50 LIRA, Ricardo pereira. Op. cit. p. 363 e 373.

51 BRASIL, Constituição da República Federativa do Brasil, de 24 de Janeiro de 1967 com a Emenda Constitucional no 01 de 17 de Outubro de 1969. Art. 160.

52 MOREIRA, Mariana. A História do Estatuto da Cidade in: DALLARI, Adilson Abreu; FERRAZ, Sérgio (Coord). Estatuto da Cidade: Comentários à Lei Federal 10.257/2001. 1 ed. São Paulo: Malheiros, 2002. p. 31-36.

53 BRASIL, Projeto de Lei n 775 de 04 de Maio de 1983.

${ }^{54}$ BRASIL, Projeto de Lei n. 2.191 de 27 de Abril de 1989.

55 BRASIL, Projeto de Lei n. 5.788 de 1990.

${ }^{56}$ BRASIL, Lei no 10.257 de 10 de Julho de 2001. Art. 3 inciso III, art. 9 e 10, art. 15 a 20.

${ }^{57}$ BRASIL, Lei no 6.766 de 19 de Dezembro de 1979. Artigo 2o §6ㅇ com redação dada pela Lei 9.785/1999.
} 
execução de planos de urbanização; o parcelamento do solo, com ou sem edificação, para sua melhor utilização econômica, higiênica ou estética ${ }^{58}$.

Igualmente ocorreu a edição de medida provisória ${ }^{59}$ que regulamentava a concessão de uso especial para fins de moradia com intuito de regularização da posse daqueles que residem em imóvel público, facultando ao particular o uso privativo de bem público embora com maior grau de estabilidade em razão da sua natureza de contrato administrativo de duração perpétua enquanto observado o fim de moradia que traduz em um direito real de natureza pública ao particular transmissível por ato inter vivos e mortis causa e oponível perante os particulares e a própria Administração Pública. ${ }^{60}$

Porém, é apenas no final da primeira década do século XXI que diante do cenário de crise financeira mundial com o recrudescimento de seus impactos negativos sobre a atividade econômica, renda e nível de emprego do País, as decorrentes restrições de crédito associado às operações de financiamento habitacional, bem como, diagnóstico da ampliação do déficit habitacional no segmento populacional de baixa renda, em razão da impossibilidade de comprovação, regularidade e suficiência de renda e aceleração do fenômeno de urbanização, que foi adotada uma política pública nacional para facilitar o acesso à moradia própria para as famílias de menor renda através da edição de medida provisória ${ }^{61}$ posteriormente convertida em lei ${ }^{62}$.

\section{O PROBLEMA DA MORADIA NO BRASIL E A REGULARIZAÇÃO FUNDIÁRIA}

A dimensão dos problemas urbanos que se encontram no Brasil - dentre os quais a questão da habitação - guarda correlação lógica com a situação econômico-social de sua população, de modo que é insustentável qualquer tentativa de solução dos problemas das cidades brasileiras sem a existência de políticas públicas com objetivo de combater o aumento da degradação ambiental, bem como, dos índices de pobreza garantindo os direitos

\footnotetext{
58 BRASIL, Decreto-Lei no 3.365 de 21 de Junho de 1941. Artigo 2o §6으 com redação dada pela Lei 9.785/1999.

${ }^{59}$ BRASIL, Medida Provisória no 2.220 de 04 de Setembro de 2001.

${ }^{60}$ DI PIETRO, Maria Sylvia Zanella. Concessão de Uso Especial para Fins de Moradia: Medida Provisória 2.220 de 04.09.2001 in: DALLARI, Adilson Abreu; FERRAZ, Sérgio (Coord). Estatuto da cidade: comentários à lei federal n. 10.257/2001. São Paulo: Malheiros, 2002. p. 161.

${ }^{61}$ BRASIL, Medida Provisória no 459 de 25 de Março de 2009.

62 BRASIL, Lei no 11.977 de 7 de Julho de 2009.
} 
fundamentais das pessoas que vivem na cidade. ${ }^{63}$ Sob tal entendimento, a questão da habitação urbana não decorre apenas do parcelamento do solo urbano irregular em núcleos urbanos desprovidos de infraestrutura e de condições de habitualidade mínima decorrentes da ocupação de áreas de proteção ambiental.

Inicialmente, o problema habitacional nas cidades brasileiras envolve a especulação imobiliária que tem fomentado o parcelamento clandestino e irregular, bem como, o parcelamento de solo urbano realizado à época que inexistiam legislações adequadas e claras sobre a matéria tornam-se desafios herdados pelo Poder Público em matéria urbanística ${ }^{64}$. Tal realidade, não se supera com a regularização fundiária de assentamentos urbanos para a população de baixa renda, ao revés, insere as ocupações regulamentadas à especulação imobiliária desvirtuando os seus fins de ocupação tornando a propriedade e tais áreas mercadoria negociável.

Igualmente, o problema habitacional ultrapassa o binômio déficit de habitações e demanda por moradia própria, mas envolve fatores sócio-econômicos como o gap entre a renda da maioria da população e os custos da habitação, a incompatibilidade entrea capacidade de financiamento das habitações e a demanda nominal, o desequilíbrio entre a estrutura rural e urbana, a concentração em instrumentos voltados apenas às deficiências operativas do mercado e a forma paliativa da abordagem ${ }^{65}$. O assentamento da população de baixa renda, portanto, sem a adoção concomitante de medidas socioeconômicas importa na persistência da miséria ou pobreza ou a ausência de serviços essenciais não conduz a realização plena do direito à moradia que depende da concretização de outros direitos fundamentais.

Por esta razão, a dificuldade de solução de tal problema urbanístico envolve a má distribuição das políticas urbanas, com a canalização dos recursos estatais para áreas ocupadas pelas classes superiores da extratificação social, seja em razão da ocupação dos cargos superiores na tecno-estrutura da Administração Pública, seja devido às limitações do exercício da cidadania não disposição de canais institucionais eficazes de reinvidicação das camadas populares ${ }^{66}$. De tal sorte, que a concretização do direito à moradia não se limita à regularização

63 SALE JUNIOR, Nélson. Novas Perspectivas do Direito Urbanístico Brasileiro: Ordenamento Constitucional da Política Urbana. Aplicação e Eficácia do Plano Diretor. Porto Alegre: Sergio Antonio Fabris Editor, 1997. p. 19.

${ }^{64}$ LEAL, Rogério Gesta. Direito Urbanístico. Porto Alegre: Renovar, 2003. p. 199.

${ }^{65}$ SEELENBERGER, Sergio H. Políticas Habitacionais e Desenvolvimento in: KACOWICZ, Mateus. Op. cit. p. 198.

${ }^{66}$ BRASILEIRO, Ana Maria. Op. cit. p. 39. 
fundiária com a concessão do título de posse ou propriedade à população carente, mas envolve a adoção de variadas políticas públicas.

Todavia, os limites financeiros - da disponibilidade de recursos arrecadados diante do crescimento das necessidades de moradia - e dos desequilíbrios espaciais - cujo crescimento dos recursos depende de ampliação da atividade econômica que não necessariamente acompanha as necessidades de gastos - gera distorção no financiamento das políticas habitacionais e sociais e igualmente impõe fator limitativo à implementação do direito de moradia àqueles que residem nas referidas áreas. ${ }^{67}$

Por efeito, a escassez ou déficit habitacional na realidade brasileira não é a causa, mas manifestação dos baixos níveis de desenvolvimento sócio-econômico de parcela substancial da população nacional que não é alcançada pela oferta do mercado convencional através do sistema de financiamento imobiliário e, portanto, não é capaz de gerar o volume adequado de habitações, bem como, não consegue ser objeto de pleno e indiscriminado de políticas habitacionais sociais com a concessão de subsídios pelo Estado Brasileiro em razão dos limites financeiro-orçamentários. ${ }^{68}$

Não se trata, portanto, a questão da habitação apenas de um problema de oferta em extensão - quantidade de moradias - mas de profundidade - permitindo atingir a diversificação da população e não somente limitar-se a mera oferta de um produto baseado em padrões alheios. Na própria habitação popular concedida pelo o Estado oferece-se uma moradia mínima, os equipamentos públicos a posteriori e o título de propriedade após a quitação dos compromissos. ${ }^{69}$

Envolve uma realidade de parcelamento ilegal, de loteamento clandestino e de construção em áreas proibidas que foi objeto de uma tutela ineficaz pelo Estado durante longo período. A utilização do solo urbano em nível mundial como uma mercadoria negociada de forma fragmentada e explorada conforme a contradição comum entre abundância e escassez com vistas ao atendimento de interesses privados. Os espaços adentram ou não dentro da lógica capitalista, criando espaços aproveitáveis ou não, sagrados ou profanos, assumindo um caráter capital e sendo o mesmo manipulado para refletir status e prestígio ${ }^{70}$.

\footnotetext{
${ }^{67}$ SILVA, Fernando A. Rezende da. Aspectos Financeiros do Planejamento Urbano. in: KACOWICZ, Mateus. Op. cit. p. 76/77.

${ }^{68}$ SEELENBERGER, Sergio H. Op. cit. p. 200.

${ }^{69}$ SEELENBERGER, Sergio H. Op. cit. p. 209.

${ }^{70}$ HARVEY, David. A Justiça Social e a Cidade. São Paulo: Hucitec, 1980. p. 240.
} 
Neste tocante, as áreas de proteção ambiental tornam-se objeto da ocupação por loteamentos irregulares e as unidades de conservação situadas em áreas urbanas acabam sendo justamente alvo de moradia, cujas consequências não são positivas para a natureza e um de seus resultados imediatos constitui uma acelerada corrida para a sua tomada, fruto da ausência do exercício regular de fiscalização através do poder de polícia estatal. ${ }^{71}$

Uma vez que as áreas ambientalmente frágeis - como córregos e rios, encostas íngremes e mangues - não interessam ao mercado legal que tolera as ocupações irregulares quando interferem nas áreas de interesse imobiliário privado, acabam sendo aquelas possíveis de ocupação para a moradia de parte da população carente e geram consequências danosas como poluição dos recursos hídricos e dos mananciais, além, das mortes por desmoronamento, enchentes e epidemias. Por efeito, há uma relação direta entre moradias irregulares e processo de degradação ambiental resultado da falta de investimento estatal e da exclusão social, duas grandes mazelas da sociedade brasileira. ${ }^{72}$

Neste giro, a proteção ao direito à moradia nas cidades brasileiras é historicamente fragilizada ${ }^{73}$, em especial, mediante reassentamentos e remoções compulsórias de áreas ocupadas pela população carente nessas áreas ambientais de forma a atingir os fins econômicos, políticos ou sociais de destinação do solo urbano que muitas das vezes se confundem com políticas de higienização ou desfavelização.

As sucessivas alterações no regime jurídico-urbanístico com fins de conformação da realidade social vigente e resolução das questões habitacionais demonstram-se inefetivos, pois o modo de apreensão da terra urbana não foi alterado:

"O modo de apropriação da propriedade implantado em nosso país, não sofreu profundas modificações o acesso a propriedade urbana, em vista das regras do mercado imobiliário continua sendo permitido apenas os setores da sociedade que possuem renda. A existência de favelas, assentamentos urbanos carentes decorrentes do processo informal de ocupações coletivas, cortiçoes, conjuntos habitacionais abanadonas, ocupados, loteamentos periféricos sem equipamentos e infra-estrutura urbana, a degradação ambiental com a poluição dos rios, lagos, represas

${ }^{71}$ CARRERA, Francisco. Cidade Sustentável: Utopia ou Realidade? Rio de Janeiro: Lumen Juris, 2005. p. $62 / 63$.

72 MARICATO, Erminia. Cidades: Alternativas para a Crise Urbana. Petrópolis: Vozes, 2001. p. 163.

73 Relatoria Nacional para o Direito Humano à Moradia Adequada e a Terra Urbana da Plataforma Brasileira de Direitos Humanos, Econômicos, Sociais e Culturais (DhESC Brasil) consta os resultados de missões realizadas entre 2007 e 2009, ou seja, anteriores à rreferida lei em 6 cidades dentre as quais no Rio de Janeiro onde se verificou negações concretas à efetivação do direito à moradia. Os relatórios estão disponíveis

em: http://www.dhescbrasil.org.br/index.php?option=com_content\&view=category\&layout=blog\&id=135\&lt emid=160 Acesso em 12.05.2014. 
e das mares, a destruição das áreas verdes, a deterioração da qualidade de vida na cidade exige um novo paradigma para o regime de propriedade." (SAULE JÚNIOR, Nelson. Op. cit. p. 56/57).

Uma vez que a lei de regularização fundiária urbana abrange assentamentos irregulares, a saber, aglomerados subnormais ocupados por coletividade de pessoas em parcelamentos informais ou irregulares com uso predominante de fins de moradia, a regularização fundiária não é poder-dever, mas dever-poder do Estado uma vez que envolve a concretização de direito fundamental social que, portanto, se vincula a eminentemente interesses públicos e não se liga apenas a interesses privados já que envolve o bem-estar de parte da população que reside em locais caracterizados pela precariedade como favelas, comunidades, palafitas e afins. Como aponta a doutrina:

“A regularização fundiária consiste em regularizar a posse e promover a urbanização do local sem recorrer à remoção dos possuidores para outros locais. A regularização fundiária é frequentemente limitada à transferência de títulos fundiários, sobretudo os de propriedade privada. A medida, alias, é preconizada como uma 'solução milagrosa' e pelas instituições internacionais é celebrizada, nos últimos anos, pelos trabalhos do economista peruano Hernando de Soto que bem desenvolve a questão de a Administração Pública opor-se a propriedade absoluta". (RIOS, Arthur. Op. cit. p. 71-72)

A regularização fundiária é assim um processo para acertamento não apenas urbanístico, mas também social da terra, ou seja, dos assentamentos irregulares ou clandestinos destinados à moradia, o que conduz inexoravelmente ao pleno desenvolvimento das funções sociais da cidade. Isto porque as funções sociais da cidade não envolvem apenas funções de gestão, mas se relacionam de forma íntima com os direitos fundamentais de forma que dentre as funções urbanísticas encontra-se a habitação e o meio ambiente. ${ }^{74}$

Ademais, a função social da propriedade urbana não se restringe ao atendimento das diretrizes fixadas no plano diretor, mas envolve o atendimento de um complexo de critérios que variam desde a adequação do direito de construir às normas urbanísticas, até a democratização das oportunidades de acesso a propriedade urbana e moradia, a correção das distorções de valorização do solo urbano, bem como, a regularização fundiária e urbanização de áreas ocupadas por população de baixa renda. ${ }^{75}$

A lei de regularização fundiária explicita como um de seus princípios a ampliação do acesso à terra urbanizada pela população de baixa renda com prioridade para sua permanência na área ocupada assegurada a melhoria das condições de sustentabilidade urbanística, social e

\footnotetext{
${ }^{74}$ RIOS, Arthur. Regularização Fundiária Urbana. Curitiba: Juruá, 2012. p. 30 e 23.

75 SAULE JUNIOR, Nelson. Op. cit. p. 174.
} 
ambiental $^{76}$. Tal permanência na área ocupada é apontada pela doutrina em razão da capacidade econômica inferiorizada de seus moradores que dificulta o acesso aos equipamentos públicos onerando os gastos com transporte e dificultando o trabalho ${ }^{77}$.

\section{OS BENS AMBIENTAIS E A REGULAÇÃO FUNDIÁRIA}

Uma vez que a ocupação do solo urbano brasileiro ocorreu de forma assimétrica sendo orientada pelas demandas da economia vigente com a exclusão de parcela da população que passou a ocupar locais sem interesse pelo mercado ou por ele não passível de apropriação como as áreas de preservação ambiental inevitável, que a regularização fundiária desses assentamentos passará uma tensão imanente com o meio ambiente.

A definição e concretização dos direitos fundamentais de terceira geração, e, num particular, os direitos relacionados ao meio ambiente, vêm propondo novos desafios e impasses para o direito, muito porque tais direitos decorrem de um novo contexto social, cultural, econômico e histórico, de onde derivam novos problemas e demandas que até então nunca haviam sido enfrentados.

Questões como o custo do uso dos recursos naturais, a plena reparabilidade dos danos ambientais, o direito ao meio ambiente saudável das gerações futuras, a eqüidade intergeracional, o objeto a ser preservado nos diversos ecossistemas, toda essa complexidade exige não só uma rigorosa definição do que seja a natureza e o gênero de direito a esta associado, mas também o debate e a proposta de soluções concretas para esses impasses mesmo que num primeiro momento não possamos pretender oferecer soluções hermeticamente perfeitas, uma vez que ainda há pouca maturidade doutrinária capaz de sustentar tal pretensão.

Para os gregos antigos, a natureza expressava uma essência que, para realizar-se, precisava "ser-no-mundo". Deste modo, ser - por essência - seria existir de uma determinada forma no mundo. Não havia uma separação entre ser e dever-ser, ou seja, a própria forma pela qual a natureza se organizava, no seu processo de composição e diferenciação, impunha a todos a maneira pela qual a totalidade social deveria ser organizada.

Nesse sentido, a natureza é um conceito ou fenômeno cultural e filosófico que, como tal, não tem direitos em si - próprios e intrínsecos -, mas sim é preservada em função do logos

\footnotetext{
${ }^{76}$ BRASIL, Lei no 10.257 de 2001. Art. 48 inciso I.

${ }^{77}$ FUKASSAWA, Fernando. Regularização fundiária urbana. São Paulo, Saraiva, 2013. p. 90.
} 
harmônico que a informa. Do conjunto normativo que tutela os recursos hídricos, a atmosfera, os solos e demais bens ambientais, não cabe a conclusão de que a natureza tem direitos que se afirmam em relação ao homem e são independentes das necessidades humanas.

No entanto, se concebermos o direito como os gregos, ou seja, como algo decorrente da ordem da natureza e ordenado por um determinado princípio e, mais do que isso, como aquilo que cabe a uma determinada sociedade segundo uma apropriação resultante da disciplina da polis, um produto ou resultado, de acordo com uma justa medida - nem mais, nem menos, do que the corresponde no todo social -, podemos vislumbrar um princípio de resposta à questão das externalidades ambientais.

Em outras palavras, muito embora o meio ambiente não se configure como um titular autônomo de direitos, o seu uso - cada vez mais exaustivo e exponencialmente degradante leva à reflexão acerca da atribuição de uma justa medida do uso dos bens ambientais, que na grande maioria das vezes não consegue ser adequadamente resguardado através dos instrumentos jurídicos tradicionais disponíveis.

Os bens ambientais, no direito brasileiro, ora são considerados como res nullius - coisa sem dono, passíveis de livre apropriação -, ora como res communes - bens de uso comum do povo, gratuito ou retribuído, conforme a sua escassez. Em ambos os casos, a apropriação subjetivista e patrimonial não oferece um regime adequado de proteção, como veremos a seguir.

O Foral e Doação da Capitania de Pernambuco a Duarte Coelho, de 24 de setembro de 1534, estabelecia que a capitania constituía-se em 60 léguas de costa, começando no Rio São Francisco e acabando no Rio Santa Cruz, sem fixação de limites terra a dentro. O donatário possuiria para si e seus herdeiros 10 léguas de terra, devendo as outras terras ser distribuídas em sesmarias a qualquer pessoa que fosse cristã, sem foro nem direito algum, exceto o dízimo devido à Ordem do Mestrado de Nosso Senhor Jesus Cristo. A Coroa reservava para si o domínio pleno de todas as minas de metais e pedras preciosas, bem como do pau-brasil e especiarias, cujo comércio por particulares é proibido a duras penas:

Dom João etc. A quantos esta minha carta virem faço saber que eu fiz ora doação (...) é conteúdo e declarado na carta de doação que da dita terra Ihe tenho passada, e por ser muito necessário haver aí foral dos direitos, foros e tributos e coisas, que se na dita terra hão de pagar, assim do que a mim e à coroa de meus reinos pertencerem, como do que pertencerem ao dito capitão, por bem da dita sua doação, eu havendo respeito à qualidade da dita terra e a se ora novamente ir morar, povoar e aproveitar, e porque se nisto melhor e mais cedo faço, sentindo assim por serviço de Deus e meu e bem do dito capitão e moradores da dita 
terra, e por folgar de lhes fazer mercê, houve por bem de mandar ordenar e fazer o dito foral na forma e maneira seguinte

Item primeiramente, o Capitão da dita capitania e seus sucessores, darão e repartirão todas as terras dela de sesmaria, a quaisquer pessoas de qualquer qualidade e condições que sejam, contanto que sejam cristãos, livremente sem foro nem direito algum, somente o dízimo, que serão obrigados a pagar à Ordem de mestrado de nosso Senhor Jesus Cristo (..) Item o pau do brasil da dita Capitania, e assim qualquer especiaria ou drogaria de qualquer qualidade que seja, que nela houver, pertencerá a mim, e será tudo sempre meu e de meus sucessores, sem o dito Capitão, nem outra alguma pessoa poder tratar nas ditas cousas, nem em alguma delas, lá na terra, nem as poderão vender nem tirar para meus Reinos ou senhorios, nem para fora deles, sob pena de quem o contrário fizer perder, por isso, toda a sua fazenda para a Coroa do Reino, e ser degredado para a llha de São Tomé, para sempre ${ }^{78}$.

O Regimento do Pau Brasil, de 12 de dezembro de 1605, determinava que o pau-brasil, empregado em tinturaria, seria propriedade da Coroa e que para cortá-lo era necessária ordem do Provedor-Mor da Fazenda, que só a concederia à pessoa idônea que não o descaminhasse. 0 corte não poderia exceder o permitido e, se o excedesse em dez quintais, daria lugar à multa de cem cruzados; em cinqüenta quintais, a açoite e degredo; e, em cem quintais, à pena de morte e de perda de toda a fazenda:

Parágrafo 1'. Primeiramente Hei por bem, e Mando, que nenhuma pessoa possa cortar, nem mandar cortar o dito páo brasil, por si, ou seus escravos ou Feitores seus, sem expressa licença, ou escrito do Provedor mór de Minha Fazenda, de cada uma das Capitanias, em cujo destricto estiver a mata, em que se houver de cortar; e o que o contrário fizer encorrerá em pena de morte e confiscação de toda sua fazenda.

Parágrafo 2'. O dito Provedor Mór para dar a tal licença tomará informações da qualidade da pessoa, que tha pede, e se delia ha alguma suspeita, que o desencaminhará, ou furtará ou dará a quem o haja de fazer.

Parágrafo 4'. E toda a pessoa, que tomar mais quantidade de páo de que Ihe fôr dada licença, além de o perder para Minha Fazenda, se o mais que cortar passar de dez quintaes, incorrerá em pena de cem cruzados, e se passar de cincoenta quintaes, sendo peão, será açoutado, e degradado por des annos para Angola, e passando de cem quintaes morrerá por elle, e perderá toda sua fazenda. ${ }^{79}$

O Código Civil de 1916 considera duas classes de bens: os bens privados (primordiais) e os bens públicos (residuais). A natureza, nesse Código, é concebida, via de regra, como uma totalidade que não se encerra nessas categorias e é considerada coisa de ninguém ${ }^{80}$. Na

\footnotetext{
${ }^{78}$ MENDONÇA, Marcos Carneiro de. Raízes da Formação Administrativa do Brasil. Foral de Duarte Coelho. Rio de Janeiro: IHGB/Conselho Federal de Cultura, 1972, tomo I, regimento III-B, p. 125-126.

${ }^{79}$ MENDONÇA, Marcos Carneiro de. Op. cit. p. 361.

${ }^{80}$ SILVA, José Robson da. Paradigma biocêntrico: do patrimônio privado ao patrimônio ambiental. Rio de Janeiro: Renovar, 2002.
} 
tradição do direito brasileiro, dispunha o Código Civil de 1916, em seus arts. 65 e 66, que a res nullius não consistia em propriedade de ninguém, mas, por direito público, seria objeto de direito de uso do povo. Daí a tendência errônea em se conceber a ocupação como exercício de direito (público) a adquirir a propriedade ${ }^{81}$. A tradição reinícola, da qual derivou o Foral de Duarte Coelho, se manteve nesse Código de acentuado viés subjetivo e privatista, e veio a legitimar a ocupação dos bens ambientais em tudo aquilo que não contrariasse os interesses do Estado.

O bem ambiental poderia ainda, nesse Código, ser considerado, enquanto macrobem (como totalidade e não recurso natural), como bem público de uso comum do povo. É o que dispunha o art. 66, I, do Código Civil, ao prever que são bens públicos de uso comum do povo os mares, rios, estradas, ruas e praças. Segundo o art. 66, I, portanto, o titular do meio ambiente era o povo ${ }^{82}$. Tal disciplina não se alterou substancialmente no direito civil com o advento do Código Civil de 2002, que manteve substancialmente os mesmos dispositivos, em seus arts. 98 e 99.

A concepção de alguns bens ambientais como res nullius, como é notório, favoreceu a sua degradação. Imaginava-se a natureza como uma fonte inesgotável de bens (Foral de Duarte Coelho, "por bem da dita doação ir morar, povoar e aproveitar") e os recursos naturais como livremente apropriáveis, sem que fosse preciso prestar contas a ninguém: aquele que primeiro se apossasse, assenhorear-se-ia das coisas. Tal regime não oferecia nenhuma garantia de proteção e, não tendo os recursos naturais um preço, suas comodidades eram usufruídas privadamente por aqueles que dispunham de mais recursos, sendo os excedentes descartados na natureza - o que onerava a coletividade -, também sem quaisquer custos.

O status de res nullius opera, assim, como um indutor econômico à exploração predatória da natureza. O historiador e brasilianista norte-americano Warren Dean, em seu

\footnotetext{
${ }^{81}$ FREITAS, Teixeira de. Esboço, art. 327, apud MIRANDA, Francisco Cavalcanti Pontes de. Tratado de Direito Privado. Tomo II. Bens. Rio de Janeiro: Editor Borsoi, 1954, § 150, 1.

${ }^{82}$ FREITAS, Teixeira de. Op. cit. p. § 150, 3: “Ordenações Afonsinas, Livro II, Título 24, § 5: 'Estradas e ruas pruvicas antiguamente usadas, e os rios navegantes e aqueles, de que se fazem os navegantes, se som cabedaaes, que correm continuadamente em todo o tempo, pero que o uso assy das estradas, e ruas pruvicas. como dos rios seja igualmente cõmuu a toda gente, e qualquer outra coisa animada, ficando sempre a propriedade dêles no Patrimonio Fiscal'; Ordenações Manuelinas, Livro II, Titulo 15, 'Real' em vez de 'Fiscal'; Ordenações Filipinas, Livro II, Titulo 26, § 8, 'Real', em vez de 'Fiscal'). Se o mar, ou o ar, ou ser semelhante, não é do território de nenhum Estado, é do Homem, 'de todo o gênero humano' (Manuel Borges Carneiro. Direito Civil de Portugal, IV, 3). Se é parte de território estatal, mas inapropriável, pertence ao povo do Estado".
} 
clássico livro "A ferro e fogo: a história e a devastação da Mata Atlântica Brasileira"83, discorre, nos 15 capítulos que compõem sua obra, sobre a história das relações entre o homem e um dos mais importantes ecossistemas mundiais, a Mata Atlântica. Sua avaliação, realizada através de um estudo pioneiro, perpassa as várias fases da interferência humana sobre esse ecossistema único, apontando as trágicas, e muitas vezes irreversíveis, conseqüências do processo. Tal panorama, conforme mostra o autor, só começou a se modificar recentemente, com o movimento universal de conscientização ecológica, que tem induzido à criação de legislação de proteção e programas de reflorestamento, educação ambiental e manejo da floresta. A continuada devastação do bioma Mata Atlântica acabou por reduzir sua constituição original a menos de $10 \%$ da área coberta originalmente, o que, independentemente de perdas relativas à sua fitofisionomia e diversidade zoológica, provocou também severas alterações climáticas e pedológicas, notadamente na região nordestina.

A efetiva proteção dos bens ambientais também não se configurou com precisão pelo fato de outros bens ambientais terem assumido, desde logo no direito brasileiro, uma estrutura publicística. Como visto no Foral de Duarte Coelho e no Regimento do Pau Brasil, o regime de proteção maior e valoração dos bens ambientais decorrente da dominialidade pública como bens de uso comum do povo destinou-se a facilitar uma maior e mais efetiva exploração econômica por parte da Coroa, degradando, igualmente, a natureza. Como se nota, a patrimonialização (pública) carrega consigo paradoxos. Com ela se combate a apropriação desmedida dos recursos ambientais, mas somente na medida em que houver um controle social da implementação da gestão desses recursos naturais, uma vez que, do contrário, o Estado pode privilegiar a concentração de riquezas e impedir o acesso da população aos recursos ambientais $^{84}$.

Melhor sorte não tiveram os animais silvestres, também considerados como bens públicos, sendo proibida, no entanto, a sua utilização, perseguição, destruição, caça ou apanha (Lei n.o 5.197/67, art. 10). Ainda assim, mais de 218 espécies de animais silvestres já se encontram na lista dos animais em extinção e pelo menos 7 dessas espécies são consideradas extintas, não sendo registrada sua presença nos últimos 50 anos. As principais causas da redução de espécies são a destruição de habitat naturais por corte de vegetação, a ocupação humana e a exploração econômica, seguidas do tráfico de animais silvestres. Calcula-se que

\footnotetext{
83 DEAN, Warren. A ferro e fogo: a história e a devastação da Mata Atlântica Brasileira. São Paulo: Companhia das Letras, 1996.

${ }^{84}$ SILVA, José Robson da. Op. cit. p. 65-66.
} 
cerca de 12 milhões de animais são retirados anualmente do país de forma ilegal, através do tráfico. A caça também é um dos fatores que exercem grandes impactos na fauna silvestre. Os animais, embora qualificados como propriedade do Estado, são apreendidos e utilizados, sem que o Estado atue com eficiência na tutela desse patrimônio.

A partir dos anos 80 do século XX, contudo, esse quadro patrimonialista e privatista assume uma configuração substancialmente diversa. A Constituição da República de 1988, em seu art. 225, qualifica o meio ambiente como um bem de uso comum do povo, um macrobem 85 , ao disciplinar que: "todos têm direito ao meio ambiente ecologicamente equilibrado, bem de uso comum do povo e essencial à sadia qualidade de vida, impondo-se ao Poder Público e à coletividade o dever de defendê-lo e preservá-lo para as presentes e futuras gerações". O artigo 2ำ, I, da Lei $n$. o 6.938/81, atribui ao meio ambiente a qualidade de patrimônio público, ressaltando a sua dominialidade como pertencendo à sociedade e não aos indivíduos ou às pessoas de direito público interno, ou seja, como um bem público de uso comum.

Esse novo desenho institucional é pleno de conseqüências jurídicas. O bem ambiental pode ser conceituado agora como um direito difuso, de natureza pública e imaterial, que todos detêm em comum, inapropriável em termos de fruição individualizada, envolvendo uma relação de equilíbrio complexa, transtemporal (para as presentes e futuras gerações), cuja defesa é aberta à titularidade de toda a coletividade. A noção de ambiente é, assim, unitária e geral, e requer proteção jurídica, dado que sua conservação se considera fundamental para o desenvolvimento da pessoa.

Isso implica, inicialmente, uma superação do modelo de pensar hobbesiano - que é o nosso, de compreender a realidade a partir do sujeito -, que decompõe o sistema social numa perspectiva individualista e esquemática para, só então, reconstruí-lo a partir dos seus supostos elementos fundantes ${ }^{86}$. O pensamento dessa nova realidade do bem ambiental não pode deixar

85 De acordo com Antônio Herman V. Benjamin, o bem ambiental, enquanto objeto de interesse ambiental, é um "macrobem", ou seja, gênero amplo, categoria única, global e abstrata que "[...] acolhe uma infinitude de outros bens [...] menos genéricos e mais materiais (microbens): a atmosfera, águas, 0 solo etc. BENJAMIN, Antonio Herman V. (Coord.). Dano ambiental: prevenção, reparação e repressão. SãoPaulo: Revista dos Tribunais, 1993, p. 60.

${ }^{86} \mathrm{Um}$ acontecimento que marca a obra de Hobbes é, sem dúvida, em definitivo, o reencontro com a ciência moderna. Primeiramente a descoberta de Euclides: Hobbes intenta seguir Euclides construindo o corpo político como a geometria constrói suas figuras, com a mesma lógica pura. Depois o contato em Pádua, com Galileu e o método de Pádua: o famoso método denominado "resolutivo-compositivo", que procede pela análise das coisas em elementos primeiros, depois recompõe os fenômenos a partir desses elementos, o mecanismo que percebe a gênese dos fenômenos pelos movimentos de seus particulares. 
de ser um pensamento da complexidade, holístico, totalizante, atento a um esforço de compreensão multidimensional e de complexas interações. Há que se ultrapassar os princípios da física social hobbesiana (ordem, clareza, distinção e disjunção) - que constituem a ciência da simplificação e cujo paradigma domina o Ocidente. Em outras palavras, há que se superar a oposição entre homem e natureza, a disjunção entre sujeito e objeto, entre espírito e matéria ${ }^{87}$. A compreensão de complexas interações implica que se situe o foco da análise jurídica na totalidade, na interrelação entre o sistema interno (o direito) e o complexo ecossistema da relação homem/natureza/sociedade. Menezes Cordeiro, na introdução à obra de Canaris, ressalta essa correlação entre o subsistema jurídico e a totalidade, impondo modificações necessárias:

O Direito - qualquer Direito - depende de uma aprendizagem, sofrida pelos membros da comunidade jurídica; tal como a própria Moral, há sempre um ministrar de códigos de conduta, do qual depende a subsistência e a reprodução dos dados normativos.

Numa sociedade primitiva, de estruturação normativa simplificada, essa aprendizagem poderia ser ministrada de modo empírico, isto é, fazendo corresponder, em termos descritivos, às situações típicas da vida, determinadas conseqüências jurídicas. Atingido, porém, um determinado patamar de desenvolvimento social, a aprendizagem requer reduções dogmáticas, isto é, generalizações simplificadas que facultem a transmissão de conhecimentos crescentemente complexos. O fenômeno é perceptível, com clareza, no próprio Direito romano. O sistema externo, antes dispensável, adquire, em tais condições, um relevo crescente: só o seu manuseamento permite conhecer as conexões materiais internas do Direito. E deve-se ter presente que tais conexões, a serem desconhecidas, não integram a cultura nem são Direito.

O sistema externo torna-se necessário e imprescindível. E quando isso suceda, ele vai bulir, de modo fatal e compreensível, com o próprio sistema interno. $\mathrm{O}$ universo das realidades jurídicas, nas suas previsões e nas suas consequências é, pela natureza cultural, logo espiritual ou imaterial, do Direito, um conjunto de possibilidades linguisticamente descritas, relativizadas mesmo à própria linguagem utilizada., As cadeias linguísticas - mesmo quando não passem por estruturas materiais - vêm, afinal, a consubstanciar as conexões propriamente jurídicas: estas

Também Hobbes tem a ambição de transportar esse método da física galileana para a filosofia civil e social (a moral e a política). Deste modo, só pode ser da unidade primeira, o homem, e sua expressão de agir, o movimento, que se deve inferir a física social. É das necessidades inatas do homem, de seu conatus, do correspectivo instinto de conservação que se deve construir a explicação do arcabouço social. Para Hobbes o indivíduo é o cerne da sociedade, o direito é concebido como uma função do sujeito (do equilíbrio entre a realização do seu conatus e o seu instinto de conservação) o que o leva a criar a sociedade civil que limite a luta de todos contra todos. Na sociedade civil, se constituirá, finalmente, do direito de cada indivíduo, um sistema de direitos subjetivos.

87 PENA-VEJA, Alfredo. O despertar ecológico: Edgar Morin e a ecologia complexa. 2. ed. Rio de Janeiro: Garamond, 2005, p. 73. 
dependem daquelas, no seu conhecimento como na sua própria onticidade.

A ordenação exterior, imprimida à realidade jurídica com puras preocupações de estudo e aprendizagem, vai moldar, em maior ou menor grau, seja as próprias proposições jurídicas, seja o pensamento geral de que vai depender a sua concretização ulterior ${ }^{88}$.

Somente assim é possível integrar ao direito os problemas da qualidade de vida (e de sua partição justa), dos limites do crescimento (como crescer sem prejudicar a todos) da reconsideração da idéia de progresso, das hipercentralizações e das hiperconcentrações (megalópoles, gigantismo industrial, hipercentralização do Estado). Por exemplo, no que concerne à questão do desenvolvimento, é necessário basear a análise do desenvolvimento sustentável numa atitude diferente em relação ao tempo histórico. Não se pode mais supor que este seja juridicamente sem validade, visto que hoje se consideram os direito da presente e futuras gerações. A temporalidade humana deverá ser congruente com a temporalidade da bioesfera e a temporalidade ética. Haverá que se fazer a correlação entre a incerteza ambiental e escolhas sociais ${ }^{89}$, decidir-se a partição do justo.

Entramos, assim, em outro campo do direito quando falamos de bens ambientais: aquele que compreende o direito não como uma função de um poder do sujeito, mas o que o percebe como uma partição social, como a justa medida dos bens que existem para serem distribuídos, segundo o melhor processo heurístico para fazê-lo.

O direito é, nessa perspectiva, um objeto exterior ao homem, uma coisa. Trata-se da mesma coisa justa (ipsa iusta res) que constitui o término do atuar justo de uma pessoa, a finalidade da virtude da justiça. A conduta justa do homem justo (dikaios) é a justiça em mim, subjetiva, enquanto o direito (dikaion) é a justiça fora de mim, no real, a mesma coisa justa, objetiva. O direito está, assim, fora do homem, in re, nas coisas justas, de acordo com uma determinada proporção, o justo meio objetivo.

Deve-se acrescentar também ao to dikaion o justo meio (meson). O justo meio é o que exige maior esforço. É mais fácil deixar completamente de beber do que ficar na medida justa. O justo meio não é uma baixa, mas um pico, o mais difícil de atingir, entre dois lados de facilidade. A virtude da justiça está no justo meio: se sou justo é porque eu não sou nem muito ávido por aumentar minha parte, nem muito desleixado para não fazer valerem meus direitos. O direito é, pois, um "meio", um justo meio objetivo, nas coisas, in re.

\footnotetext{
88 CANARIS, Claus-Wilhem. Pensamento sistemático e conceito de sistema na ciência do direito. 2. ed. Lisboa: Calouste Gulbenkian, 1996, p. LXVII/LXIX.

89 PENA-VEJA, Alfredo. Op. cit, p. 97-98.
} 
O direito, assim pensado, não é rigorosamente individual, não supõe para o indivíduo somente um ativo, apenas vantagens; o direito de uma pessoa, isso que the deve ser dado, aquilo que ela merece, não é "subjetivo", não se refere somente a um indivíduo, mas implica necessariamente uma relação entre indivíduos. É o resultado de uma repartição. O direito é apenas um atributo da pessoa, não é exclusivamente seu na medida em que é primordialmente o bem de outrem.

Consoante esses aspectos, é possível se estabelecer as características dessa categoria sui generis de bem, o bem ambiental.

O meio ambiente é uma totalidade, nesse sentido se constitui, como vimos, num macrobem. Sua natureza é a de uma coisa comum a todos (communium ominium). Os bens ambientais $^{90}$ ("microbens") como elementos que constituem o meio ambiente (macrobem), possuem a mesma natureza pública de uso comum (communes omnium). Logo, a dupla afiliação vai dar ensejo a um regime de responsabilidade igualmente duplo. Uma ação degradadora está provocando danos ao mesmo tempo ao macrobem e ao microbem, e a reparação deve ser de tal magnitude que possibilite a recuperação da res (ou das res) afetada individualmente e também do meio ambiente ${ }^{91}$.

O meio ambiente é indisponível, ele não pode ser negociado. Sendo res omnium, não está na titularidade do Poder Público poder dispor dele. Deve-se ter, contudo, cuidado ao expressar essa característica. Sendo algo próprio ao interesse de todos, é claro que deverá atender a todos. Um número muito maior de indivíduos habitando a biosfera significará um novo nível de equilíbrio ambiental, por vezes, menor do que existia anteriormente.

Neste sentido, pressupor uma ordem de natureza significa dizer que o tempo é uma dimensão crítica das formas de reparação. Por isso, sendo a humanidade parte integrante da natureza, estando submetida às mesmas leis ecológicas de outras espécies, o que cabe preservar, para a sobrevivência e frutificação da espécie, é a manutenção dos grandes equilíbrios naturais e não de quaisquer espécies ou mesmo de certos ecossistemas. Do mesmo modo, o horizonte temporal limita a linguagem daquilo que podemos considerar direito. Só pode ser inferida uma compensação naquilo que expresse um horizonte geracional previsível e necessário. Não se pode impor custos a uma sociedade por aqueles que sequer estão em uma perspectiva temporal exeqüível.

\footnotetext{
90 Também denominados, nessa acepção de microbens, recursos naturais.

91 BENATTI, José Helder. O meio ambiente e os bens ambientais. In: RIOS, Aurélio Virgílio Veiga; IRIGARAY, Carlos Teodoro Hugueney. O direito e o desenvolvimento sustentável. São Paulo - Petrópolis: Instituto Internacional de Educação do Brasil, 2005, p. 207.
} 
Outro aspecto relevante é a indivisibilidade e a não exclusão dos benefícios: o bem ambiental não pode ser dividido entre aqueles que o utilizam, não podendo ocorrer sua apropriação privada, devido ao caráter difuso da titularidade. Todos os indivíduos têm direito ao meio ambiente, até mesmo as gerações futuras ${ }^{92}$.

Assim sendo, a complexidade do conceito de bem ambiental, seu caráter holístico, irão suscitar novas soluções de direito. Superado o entendimento do meio ambiente como res nullius e revelada a insuficiência da simples patrimonialização pública sem controle de gestão dos usos do bem ambiental, cabe agora repensá-lo a partir de seu escopo, de sua função, protegendo-o em vista de suas finalidades.

Note que não se adota, portanto, uma concepção compartimentalizada e quase dualizada da concepção de meio ambiente em uma espécie natural e outra artificial, uma vez que a distinção é meramente didática reconhecendo que o meio ambiente resulta da interação dos seus elementos naturais e construídos, mas que devem ser considerados ao se tratar de um sistema de proteção ambiental capaz de garantir a tutela e eficaz garantia da qualidade de vida saudável, bem como, devem ser tidos e valorados ao buscar-se definir um modelo de sustentabilidade não apenas social, mas também ambiental.

Considera-se, portanto, que o campo de atuação do direito ambiental, bem como, a sua tutela, não se restringe apenas o ambiente natural, mas também o cultural e o artificial e tendo em vista que a formação e o desenvolvimento do primeiro ocorrerá no meio urbano em um ambiente precipuamente artificial, demanda a integração dos aspectos naturais e culturais além de um obrigatório estudo transdisciplinar entre o direito à cidade e ambiental como antes demonstrado. ${ }^{93}$

Tão pouco, utiliza-se uma concepção biocêntrica de natureza com a consideração da existência de direitos próprios que se afirmam em relação ao homem e independente de suas necessidades. Parte-se da natureza como um conceito ou fenômeno cultural e filosófico, de forma que é o homem em sua interrelação com todo que preenche a integralidade deste conceito e a natureza apenas haure o seu sentido dessa simbiose informada com o homem que é o fundamento último da proteção pela ordem jurídica. ${ }^{94}$

\footnotetext{
92 Idem. Ibidem.

93 HUMBERT, Georges Louis Hage. Direito Urbanístico e Função Socioambiental da Propriedade Imóvel Urbana. Belo Horizonte: Fórum, 2009. p. 43.

${ }^{94}$ MOTA, Mauricio Jorge Pereira da. O conceito de natureza e a reparação das externalidades ambientais negativas. Revista eletrônica da Faculdade de Direito de Campos, Campos dos Goytacazes, RJ, v. 2, n. 2, abr. 2007. p. 13.
} 
Neste vértice, embora se perceba uma tendência reforçada nas experiências constitucionalistas latino-americana de referência ao paradigma biocêntrico, adota-se para fins deste trabalho uma concepção antropocêntrica na tutela do meio ambiente da proteção da natureza com referência ao homem, fim em si mesmo e objeto central da tutela jurídica. Entende-se a sustentabilidade como a proteção do meio ambiente no desenvolvimento para as para as gerações atuais e na preservação para as gerações futuras.

Também, não se considera que o direito ao meio ambiente ecologicamente equilibrado assume na regularização fundiária pólos opostos, mas inter-relacionam de sorte que o direito ao meio ambiente pode ser tido como salvaguarda deste, uma vez que é pré-requisito para as condições dignas e adequadas de vida e a conseqüente exigência da atuação positiva do Estado visando o bem-estar e a melhoria das condições de vida dos cidadãos, bem como, o direito a moradia alberga aquele uma vez que se liga a o grupo de sujeitos indeterminados que buscam a sua satisfação em uma perspectiva comunitária, de forma que sem a tutela efetiva da moradia e regularização das condições subhumanas de habitação não há como se garantir o meio ambiente equilibrado ${ }^{95}$. Apenas demanda uma hermenêutica capaz de garantir o seu não reducionismo:

"Os valores ambientais, ecológicos, de qualidade de vida, não são, no quadro da hipótese do Estado de Direito Ambiental, valores exclusivos nem excludentes, necessariamente prevalecentes, com dignidade hierárquica superior a qualquer outro objetivo fundamental constitucionalmente recebido. Serão antes tarefas prioritárias, sim, mas plasmadas em normas constitucionais, que terão de ser integradas num horizonte plural (diversificado e intrinsecamente concorrente ou conflitante) de princípios rectrizes e de outras normas-fim, segundo um princípio de concordância prática, não compatível com quaisquer formas de reducionaismo" (RANGEL, Paulo Castro. Concentração, programação e Direito do Ambiente. Coimbra: Coimbra Editora, 1994, p. 22).

A concretização do direito ao meio ambiente, portanto, não se limita a instituição de espaços destinados à proteção ambiental na cidade com a respectiva delimitação e implementação do regime jurídico legalmente estabelecido, mas igualmente através instituição de normas que produção modificações nas normas instituidoras de espaços especiais ambientais garantindo um ambiente saudável essencial à condição adequada de vida. Igualmente, a realização do direito à moradia não se restringe à delimitação de áras especiais

\footnotetext{
${ }^{95}$ DUARTE, Marise Costa de Souza. Meio Ambiente e Moradia: Direitos Fundamentais e Espaços Especiais na Cidade. Curitiba: Juruá, 2012. p. 46-47
} 
de interesses sociais, mas envolve a permanência dos locais onde a população carente por força de suas circunstâncias sociais e econômicas foi levada a ocupar na sociedade. ${ }^{96}$

Neste sentido, não se liga, portanto, estritamente ao meio ambiente, mas envolve também a garantia de bem-estar e direitos básicos - moradia, saneamento, alimentação e outros - a todos que residem ou estão no núcleo urbano. Isto porque o meio ambiente enquanto direito humano é o ambiente ao qual a pessoa projeta seu direito no entorno físico mais imediato ao seu ser, no qual desenvolverá sua personalidade e se projetará os direitos fundamentais ao qual possui. ${ }^{97}$

Assim, não é possível sustentar proteção ao meio ambiente e sustentabilidade da cidade mediante a exclusão de bairros e a segregação das comunidades de baixa renda sem necessária a integração das áeas excluídas aos centros urbanos. No caso do Rio de Janeiro onde a favelização na década de 30 e 40 adveio da fragmentação das comunidades e implementação de setores e regiões voltadas pra a ocupação urbanística da cidade, a remoção das favelas da zona sul na década de 50 e 60 com a caracterização do "favelado" ou "suburbano" e o reconhecimento das ocupações irregulares e clandestinos da década de 80 e 90 do século anterior ensejam necessidade de nova compreensão de sustentabilidade: ${ }^{98}$

Partindo da compreensão que as funções sociais da cidade correspondem na realidade interesses difusos uma vez que não é possível identificar quais sujeitos - proprietários, moradores, trabalhadores, migrantes - são afetados pelas atividades desenvolvidas na mesma ${ }^{99}$ é inevitável que o meio ambiente sadio e a condição digna de vida enquanto fins dessas funções sociais da cidades não guardam entre si qualquer tipo de hierarquia, mas antes representam igualmente objetivos e valores a serem igualmente perseguidos e realizados de forma concomitante.

Sob tal ordem, os espaços territoriais especialmente protegidos e inseridos nas cidades que se sujeitam a regimes especiais de proteção com limitações integrais ou parciais tendo em vista a necessidade de conservação da sua biodiversidade ${ }^{100}$ não podem ser o único vetor a orientar a concepção de sustentabilidade, mas igualmente a realização do direito a moradia com a regularização fundiária das ocupações irregulares em tais locais não pode ser tutelado

\footnotetext{
96 DUARTE, Marise Costa de Souza. Op. cit. p. 72.

${ }^{97}$ CARRERA, Francisco. Op. cit. p. 39 e 41.

98 CARRERA, Francisco. Op. cit. p. 54/55 e 57.

99 SAULE JUNIOR, Nelson. Op. cit. p. 61.

100 SILVA, José Afonso da. Direito Ambiental Constitucional. São Paulo: Malheiros, 2009. p. 233.
} 
ignorando os impactos ambientais negativos e os possíveis danos causados às gerações atuais e futuras.

Sob o influxo de uma ampla tutela pelo regime constitucional e infraconstitucional constitui o meio ambiente equilibrado um direito fundamental que se irradia sobre o sistema jurídico, atuando como vetor interpretativo de normas, categorias e institutos dentre os quais o direito à propriedade de forma a garantir que junto à sua função social contemple-se o conteúdo de proteção do meio ambiente saudável resultando na síntese de uma função socioambiental da propriedade rural e urbana. ${ }^{101}$

Neste viés, de direitos intimamente ligados e igualmente tutelados pela ordem jurídica dentro da problemática adotada e da hipótese levantada utiliza-se como marco téorico o reconhecimento da funcionalização sócioambiental sob a concepção liberal individualista da propriedade privada impondo na regularização fundiária de assentamentos urbanos em áreas de proteção ambiental uma interpretação capaz de proteger as finalidades sociais envolvidas.

\section{A PROTEÇÃO DA OCUPAÇÃO PELA TUTELA JUDICIAL}

Diversas teorias procuram explicar porque se defende a posse, situação normalmente efêmera ou aparentemente efêmera. As principais teorias foram divididas em dois grandes grupos: teorias absolutas e teorias relativas. O primeiro grupo em resumo sustenta que a posse deve ser protegida (defendida) por si mesma como situação fática a que se atribuem efeitos, independente de qualquer titulo jurídico, em decorrência de ser uma manifestação da vontade individual que se realiza sobre as coisas ou porque é um fato social produtor de interesses próprios, de que devem ser reconhecidos pelo sistema. Já as teorias relativas sustentam dentre outras hipóteses que se protege a posse pela necessidade de se proteger outros direitos, que sem essa proteção, não se poderiam exercer em toda plenitude ${ }^{102}$, como a propriedade, a pessoa do possuidor, a paz social, o interesse social ${ }^{103}$.

Em verdade, como salienta o pranteado civilista Caio Mário da S. Pereira, desde a idade média, como também nos tempos modernos, "quer nos países em que a propriedade é sedimentada nas bases de velha tradição, quer naqueles outros em que a competição pelo aproveitamento de amplas extensões territoriais dá maior ênfase à affectio tenendi - sempre a

\footnotetext{
101 HUMBERT, Georges Louis Hage. Op. cit. p. 121-122.

102 RODRIGUES. Manuel. A Posse. Estudo de Direito Civil Português, Almedina, Coimbra, 1996, p. 24

103 PEREIRA.Caio Mario da Silva. Instituições de Direito Civil. Direitos Reais. 20ạ ed, Forense, 2009, atualizada por Carlos Edison do R. Monteiro Filho, p. 30.
} 
posse ocupa a mais relevante função social, e sua proteção reclama maior atividade do aparelho judiciário". ${ }^{104}$

Como entidade econômica e socialmente relevante a posse autônoma, isto é, aquela que não é decorrência do direito de propriedade deve ser protegida por si mesma, afastando-se da ideia de satélite da propriedade para astro com luz própria. Não que a posse decorrente do jus possidendi não mereça proteção, pois assim afirmar seria um absurdo. Mas essa posse quando gera litígios em razão de seu desdobramento em decorrência de relações obrigacionais (por ex. contrato locação, comodato) ou relações reais (por ex. usufruto, uso, habitação, superfície, servidão, penhor, anticrese, alienação fiduciária) atrai o vicio da precariedade, não sendo de complexidade as demandas que a envolvem.

Contudo, naquelas que nascem de um ato de apossamento desvinculado de qualquer relação jurídica, essa sim, demanda maior complexidade causando, sua defesa, perplexidade para alguns que a consideram como um ato de usurpação que deve ser combatido e para outros a injustiça do desapossamento daquele que deu uma função social a terra.

O fato que não se pode ignorar é que, excluindo-se os casos de violência na tomada da posse, que, diga-se de passagem, são raros, a grande maioria das situações possessórias nascem da tomada da posse de coisas que estão sem utilização pelo titular do direito sobre a coisa, seja porque tem o direito com fim de investimento, formando, por vezes, banco de terras para alienação futura quando as condições de mercado melhorarem, não raro à custa do investimento de todos através de recursos públicos em instalações de equipamentos urbanos tais como pavimentação de vias de acesso, iluminação publica, instalação de praças etc.. seja, porque não tem interesse em nenhuma utilização naquele dado momento. Em outras palavras naquelas situações em que o titular não cumpre com a função social do bem.

De um modo geral esses imóveis estão vazios e sem qualquer utilização, possibilitando assim o ingresso daquele que se tornará possuidor logo após a conversão da detenção inicial em posse quando se estiver diante de obstáculos que impeçam a aquisição imediata da posse como a clandestinidade e a violência (segunda parte do art. 1.208 do $\mathrm{CC}^{105}$ ). Mas em certa medida esse ato de ingresso, deve ser reconhecido, como imediata aquisição da posse, haja

\footnotetext{
104 PEREIRA.Caio Mario da Silva. Instituições... Op. cit. Direitos Reais. p. 30;

105 BRASIL, Lei Federal no 10.406 de 10 de Janeiro de 2002. Art. 1.208: "Não induzem posse os atos de mera permissão ou tolerância assim como não autorizam sua aquisição os atos violentos, ou clandestinos, senão depois de cessar a violência ou a clandestinidade."
} 
vista que nos termos do artigo 1204 do Código Civil, ${ }^{106}$ coerente com a doutrina objetiva da posse adotada na maioria dos dispositivos do código, deve ser considerada adquirida a posse tão logo seja possível a pratica de atos, em nome próprio, inerentes à propriedade, sendo a principal manifestação nesse caso, a utilização da coisa no interesse próprio seja morando seja plantando. Na proteção da aparência de proprietário consubstanciada na ideia de que a posse é a visibilidade do domínio não é possível distinguir os sujeitos que estão no exercício de atividades junto à coisa. Como já salientava Lafayette em nota de rodapé do primeiro manual sobre Direito das Coisas no Brasil, os "atos possessórios, como o de cercar o terreno, o de cultivá-lo, o de cortar árvores, se confundem no ponto de vista material com os atos dominicais do proprietário." 107

A toda evidência, que ainda que seja necessário admitir certa abstração na caracterização da posse e da figura do possuidor, isto é, a dissociação, em certo momento na existência e caracterização do fenômeno possessório do elemento fático, presente de regra em sua aquisição e manutenção, quando por ex., não se está em contato direto com a coisa objeto da posse mas que mesmo assim ainda se tem posse no aspecto de que a coisa está à sua disposição. ${ }^{108}$ Essa abstração é necessária para preservar também a posse, pois do contrário seria o mesmo que afirmar que se o cidadão saiu de sua casa para ir trabalhar outrem nela pode entrar, o que seria um absurdo teórico, prático e poria em risco a paz social.

De certo que não se está livre de tal violação ocorrer, mas nessas poucas hipóteses, excepcionalmente o Estado autoriza a autotutela do direito, situação que se dá raramente depois que o estado chamou para si o poder de dizer o direito e solucionar os conflitos de interesse, através do chamado desforço imediato. Além do que, o art. 1224 do Código Civil fixou que só se considera perdida a posse para quem não presenciou o esbulho, quando, tendo noticia dele se abstém de retomar a coisa ou, tentando recuperá-la, é violentamente repelido,

\footnotetext{
106 BRASIL, Lei Federal no 10.406 de 10 de Janeiro de 2002. Art. 1.204: "Adquire-se a posse desde o momento em que que se torna possível o exercício, em nome próprio, de qualquer dos poderes inerentes à propriedade."

107 PEREIRA, Lafayette R. Direito das Coisas. Rio de Janeiro: Livraria Freitas Bastos S.A., 6ạ ed, 1956, p. 32.

${ }^{108}$ Vale lembrar que se tem posse mesmo quando se ausenta do imóvel para retornar posteriormente ou do veículo quando estacionado num shopping ou na própria residência do sujeito, porque em estado de abstração é necessário para não retornarmos a discussão do passado sustentada por alguns teóricos, fortes no elemento fático da posse que todas as vezes que se saísse e voltasse a um imóvel durante um dia, se estava adquirindo e perdendo a posse em cada ato isolado. Veja a proposito a monumental obra a respeito do romanista brasileiro PEIXOTO, José Carlos de Matos. Corpus e animus na posse em Direito Romano. Rio de Janeiro: Typ. do. Jornal do Comércio Rodrigues e C. 1936.
} 
abrindo assim a oportunidade do ajuizamento da ação de reintegração com base no art. 560 do novo Código de Processo Civil.

Por certo que a situação de apossamento da coisa por um estranho ou por um considerável número de pessoas só se torna possível quando o titular do direito sobre a coisa dela se descuidou por si mesmo ou por eventuais representantes, por não agirem com zelo e cuidado sobre a coisa. Se houver violência ou clandestinidade a situação daquele que ingressou na coisa será de mero detentor, não tendo, em face do titular do direito, proteção possessória porque posse não tem ainda. Mas uma vez cessada ou inexistente esses atos que viciam a tomada da coisa, a situação converte-se em posse, merecendo então proteção.

Atente-se, contudo, que para o exercício ação de manutenção ou de reintegração da posse o autor deve provar a sua posse (art. 561 inc. I do CPC) e, só com esta prova é possível falar em esbulho ou em risco de perda que justifique as ações possessórias de maior relevância, considerando que na primeira hipótese alguém tomou a posse do autor e na segunda hipótese alguém a está ameaçando. Para tanto, será necessário examinar, no caso concreto, se o autor da ação atende ao disposto nos artigos 1.196, 1.204 do Código Civil e já não se dera a hipótese prevista no artigo 1.223 do mesmo código. O primeiro diz respeito à caracterização de alguém como possuidor; o segundo quando alguém adquire ou tem posse e o terceiro quando alguém não tem posse. Esse último, no particular, assinala que cessado o poder de fato sobre o bem, considera inexistente a posse, ainda que seja possível recuperá-la por desforço imediato (se preenchido os requisitos deste - §1으 do art. 1.210 do CC) ou via ação possessória.

Mas repita-se, na maioria destas situações de apossamento da coisa de modo individual ou coletivo o imóvel está sem qualquer utilização, sem qualquer função social, o que faz acrescentar um componente importante no exame da demanda: quem merece tutela o autor que não cumpre com a função social do bem objeto de sua titularidade ou o possuidor ou possuidores que dão ou pretendem dar com a moradia ou cultivo, conforme seja área urbana ou rural, função social a posse?

Esse deve ser o enfoque atual: ausência de função social da propriedade em confronto com a função social da posse. Qual situação é digna de tutela? Qual delas está em conformidade com os princípios constitucionais que agora o Código de Processo Civil inseriu na sistemática processual? Assim, se já não se mostravam de fácil solução as ações possessórias com mais esse componente, se tornaram demandas complexas, que demandam atenção especial dos magistrados, defensores públicos, advogados, M. Público, que estão diretamente ligados aos litígios, além de outros segmentos da sociedade civil. 
Essa, nos parece é a grande dificuldade das chamadas ações possessórias: quando se deve reconhecer que alguém adquiriu e ou que alguém perdeu a posse com os novos contornos que tem a propriedade e a posse para saber a qual das partes se deve conferir proteção judicial. O caso concreto ministrará elementos, aos menos indiciários, de inicio para tal juízo.

Vale observar, neste passo, as ponderações de Humberto T. Junior:

O que a Constituição protege é o direito de propriedade usado regularmente, sem abusos, e com ressalva da sua função social (C.F. artigo 153, § 22). Nenhum direito, de ordem patrimonial, é absoluto, de maneira a assegurar ao seu titular o exercício abusivo e sem as limitações impostas pela convivência em sociedade." 109

Na mesma linha e de modo mais direto no que diz respeito às demandas posse $x$ propriedade Didier Junior enfatiza:

"Desde modo, pode-se afirmar que a Constituição de 1988 criou um novo
pressuposto para a obtenção da proteção processual possessória: a prova
do cumprimento da função social. Assim, o art. 927 do CPC que enumera
os pressupostos para a concessão da proteção possessória, deve ser
aplicado como se ali houvesse um novo inciso (o inciso V), que se reputa
um pressuposto implícito, decorrente do modelo constitucional de
proteção da propriedade. A correta interpretação dos dispositivos
constitucionais leva à reconstrução do sistema de tutela processual da
posse, que passa a ser iluminado pela exigência de observância da função
social da propriedade."

Havendo posse, que se passou a chamar de posse civil e que chamo de posse simples

(sem exercício de qualquer função) que não pode ser ignorada diante da potencialidade de uso que representa para o titular do domínio, deve-se refletir, numa eventual demanda, se ela merece algum tipo de proteção. Entendo que não, pois o titular não transformou o estado de potencia em uso, mas, não se pode ignorar seu direito de defender o seu titulo. O que se quer dizer é que não se deve deferir proteção liminar numa situação que não se evidencie o cumprimento da função social da propriedade, como prova pré-constituída à semelhança com o direito líquido e certo protegido por mandado de segurança.

Neste sentido Fachin salienta que "o largo alcance da função social não é congruente com o deferimento de proteção possessória ao titular do domínio cuja propriedade não cumpra integralmente sua função social. E que ficou sem proteção possessória constitucional a propriedade que não cumprir a sua função social."111

109 THEODORO JUNIOR, Humberto. Posse e Propriedade. São Paulo: Livraria e Editora Universitária de Direito Ltda, 1988, p. 14.

110 DIDIER JUNIOR, Freddie. A função social da propriedade e a tutela processual da posse. Revista de Processo 2008 - Repro 161, p. 18.

${ }^{111}$ FACHIN, Luiz Edson. O estatuto constitucional da proteção possessória. Leituras complementares de Direito Civil. Cristiano C. de Farias (coord). São Paulo: Jus Podim, 2007. 
Tal qual a propriedade é considerada um direito fundamental o "descumprimento do dever social de proprietário significa uma lesão ao direito fundamental de acesso à propriedade" e nesta hipótese "as garantias ligadas normalmente à propriedade, notadamente à da exclusão das pretensões pessessórias de outrem, devem ser afastadas" conforme magistério de Fabio Comparato. ${ }^{112}$

No parágrafo 10 do art. 554 o legislador de 2015, atento aos problemas sociais decorrentes da má distribuição de nossas terras (urbanas e rurais), iniciado, pode-se dizer ao tempo da colonização e aprovado, em parte, pela primeira lei que regulou a distribuição de nossas terras - Lei 601 de 1850 - estabeleceu que no caso de ações possessórias em que figure no polo passivo grande numero de pessoas, serão feitas a citação pessoal dos ocupantes que forem encontrados no local e a citação por edital dos demais, intimando-se o Ministério Público e se envolver pessoas hipossuficientes economicamente, será necessária a intimação da Defensoria Pública.

Cuidou o dispositivo das chamadas demandas coletivas da posse, qualificação a ser preenchida no caso concreto em razão da utilização de conceitos jurídicos indeterminados tais como "grande numero de pessoas" e "pessoas em situação de hipossuficiência econômica" adotando sistemática semelhante ao Código Civil de 2002 nos $\S \S 4$ 4 e 5o do art. 1228 hipótese chamada por alguns autores de: usucapião expropriatório, usucapião social, desapropriação privada, desapropriação judicial, exceção de não funcionalização social do domínio. ${ }^{113}$

As demandas coletivas da posse trazem para a temática da posse o drama social vivido em geral nas grandes cidades, por pessoas que buscam por um espaço que lhe sirva de abrigo quiçá de moradia e demanda maior atenção do interprete e do operador como se verá a seguir.

Para além do aspecto de natureza processual - como realizar a citação nas demandas que envolver um considerável número de pessoas e de uma primeira impressão que tenha como pano de fundo mais uma modalidade de proteção da propriedade, possibilitando o autor da ação possessória, que neste tipo de demanda invariavelmente é o proprietário e muita das vezes personalizado em grandes empresas, algumas simplesmente na condição de investidoras do mercado imobiliário e outras com propriedades que servem ou já serviram ao desenvolvimento de atividades do agronegócio e de atividades empresarias urbanas, a estar

112 COMPARATO. Fabio Konder. Direitos e deveres fundamentais em matéria da propriedade. Revista do Centro de Estudos Judiciários, v. 1, n. 3, p. 97.

${ }^{113}$ A respeito deste dispositivo consulte: TORRES, M. A.A função social da posse no Código Civil. TORRES, M. A. de A. e Mota, Mauricio J. P., in Transformações do Direito de Propriedade Privada. Rio de Janeiro: Ed. Elsevier, 2009, p. 41/46 
seguro que logrará identificar todos os "invasores" e citá-los de um jeito ou de outro para que nenhum deles possa alegar o principio da relatividade dos efeitos de uma decisão judicial ou talvez, uma regra para reprimir os movimentos organizados que lutam pela terra rural (MST e outras entidades) ou pela moradia urbana (MTST - movimento dos trabalhadores sem teto). ${ }^{114}$

Não creio que tenha o dispositivo, tais objetivos, em especial porque se assim fosse teria determinado, por. ex. a citação do líder da "invasão" porque de um modo geral tem um líder (que por vezes é indiciado ou preso), mas deve-se atentar, contudo, que na grande maioria da tomada da posse terra - urbana ou rural, por movimentos organizados estes tem objetivo de criar um fato politico para atrair a atenção da sociedade e das autoridades que a representam para a necessidade de desapropriar terras no campo para os trabalhadores rurais ou para construção de moradia para os habitantes das cidades que não tem teto. Esses movimentos, salvo raras exceções, não desejam a continuidade da situação possessória na área invadida.

Contudo, outros grupos não tão organizados assim e premidos pela necessidade em comum dos membros do grupo, procuram agir de modo conjunto objetivando sim a posse de determinada parte do solo urbano ou rural com finalidades mais duradouras como a moradia e o cultivo. É desses grupos, creio, que o dispositivo em referencia resolveu conceder destacada atenção.

No entanto o dispositivo acima referido traz um aspecto muito importante e que reclama uma leitura atenta para além do texto, isto é, para uma leitura sistemática da nova ordem processual introduzida pelo código de processo civil de 2015, por força da inserção de padrões axiológicos de interpretação. Há então como pano de fundo uma questão social prévia a ser considerada antes de qualquer juízo de conteúdo jurídico.

Assim, ainda que inserido no capítulo das ações possessórias, num primeiro momento deve-se abstrair da questão possessória para atingir a finalidade implícita contida no referido dispositivo, a proteção das pessoas envolvidas no conflito coletivo. É uma disputa entre um direito de cunho patrimonial e um direito à vida e a segurança jurídica. Por certo, que a questão patrimonial é de somenos importância nesta situação. Somente deve ser considerada ao final da demanda, se for ela merecedora de tutela, conforme já exposto ao longo deste texto.

\footnotetext{
${ }^{114}$ Sobre estes movimentos sociais, consulte GARCIA, José Carlos. De Sem-Rosto a Cidadão: A luta pelo reconhecimento dos Sem-Terra como sujeitos no ambiente constitucional brasileiro. Rio de Janeiro: Lumen Juris, 1999.
} 
Deve-se então primeiro atentar (ainda que não se possa afirmar que tenha sido este o objetivo do legislador), qual a interpretação que melhor se adequa ao caso analisado cotejando os princípios constitucionais aplicáveis à situação, inseridos que foram na dogmática processual pela porta de seu artigo 1ํ. Não será necessário, então, investigar num primeiro momento se está o magistrado diante de uma situação na qual o (s) autor(es) tinham posse e a perderam pelo ato dos réus ou se já houve aquisição da posse pelos réus ou se há da parte destes mera detenção independente ${ }^{115}$ que não é digna de tutela possessória já que de que posse não se trata.

Primeiro ponto a ser examinado pelo juiz é qual impacto fático-social sua decisão liminar de reintegração (porque na ação de manutenção só há ameaça da posse e em principio não haverá impacto numa decisão de manutenção, porque pressupõe que o autor esteja na posse) poderá causar, considerando o numero de pessoas envolvidas na situação e as peculiaridades dos componentes do grupo (homens, mulheres, crianças, idosos, condição de saúde, perfil social e econômico e outros elementos dignos de atenção), levando-se em consideração que a experiência indica que tais reintegrações são essencialmente traumáticas para as pessoas, com risco de dano a integridade, inclusive daqueles que representam o estado na execução da medida judicialmente determinada.

Isso porque a escassez de moradia para a população de baixa renda, que são na quase totalidade os réus das demandas coletivas de posse, é algo patente e que apesar dos esforços dos governos e entidades, parece infindável. Segundo registro de João Whitaker com base em pesquisas realizadas por instituições brasileiras, nas grandes metrópoles tem em média entre 40 a 50\% de sua população vivendo na "informalidade urbana" (favelas, cortiços e loteamentos clandestinos" configurando uma "inadequação físico-construtiva e ambiental da habitação e/ou entorno" aliados "a ilegalidade da posse ou do contrato de uso". ${ }^{116}$

\footnotetext{
${ }^{115} \mathrm{~A}$ detenção, como se sabe, pode ser subordinada ou dependente como nas hipóteses indicadas do art. 1.198 do CC que é aquele que mantem relação jurídica com o titular da posse e cumpre ordens dele e, detentor independente, que é aquele que tem a detenção da coisa desvinculado de qualquer relação jurídica com o titular do direito sobre a coisa e que mantém a condição de detentor enquanto não se converter em posse a detenção que exerce sobre a coisa, como nos casos da parte final do art.1.208 do $C C$, enquanto não cessar a violência e a clandestinidade.

${ }^{116}$ FERREIRA, João Sette Whitaker. A cidade para poucos: Breve história da propriedade urbana no Brasil. Anais do Simpósio "Interfaces das representações urbanas em tempos de globalização", UNESP Bauru e SESC Bauru, 21 a 26 de agosto 2005, p.1, apud FERREIRA, Antonio Rafael Marchezan. Tutela possessória e a remoção forçada de grupos vulneráveis e famílias de baixa renda, in Revista Eletrônica de D. Proc. Civil, p. 84.
} 
Por certo que esse problema não é só nosso. Registra Antonio Marchezan Ferreira com base em dados coletados em Geoffrey Payne e Alan Durand-Lasserve, que evidências não empíricas sugerem que 30 a 50\% da população urbana "dos países em desenvolvimento não possuem qualquer titulo que ateste a segurança de sua posse, ou seja, os moradores vivem majoritariamente sob um informal sistema de posse - que se traduz em ocupação de terra e/ou moradias ilegais, quase-legais, toleradas ou legitimadas" e que um levantamento realizado pelo Centro de Direitos da Habitação e Despejos (Centre on Housing Rights and Evictions - COHRE) os despejos forçados afetaram mais de 18 milhões de pessoas entre os anos de 1998 a $2008 .{ }^{117}$

Enquanto se discute se às necessidades vitais e a satisfação delas configura direito do homem, o espaço físico terra vai sendo ocupado por apropriação sem outro limite "que não o da capacidade econômica aquisitiva de qualquer proprietário, o que demonstra enorme desproporção existente entre o poder do mercado de terras e o poder normativo das necessidades dos não-proprietários." 118

Segundo o registro de Regina Carvalho, na questão da terra urbana tem prevalecido o interesse de setores mais capitalizados e das classes sociais mais poderosas, que fazem valer suas propostas, controles e mecanismos discriminatórios e, a falta de intervenção adequada do Estado, reflete em "elitização crescente de certas áreas da cidade e em expulsão e periferização das classes e rendas mais baixas", sendo a cidade movida pelo lucro, isto é, a produção do espaço urbano se orienta pela "disputa intercapitalista para apropriação do sobrelucro gerado na construção da terra urbanizada ou na mudança de uso, por parte dos que mais lucram com a produção do espaço urbano, o circuito imobiliário."119

Num passado, não muito distante (tomando como padrão a história de um povo), a cidade do Rio de Janeiro, recebeu após a abolição da escravatura um fluxo de escravos que encontra no seio da cidade um contingente de imigrantes europeus, igualmente expulsos do campo, todos à procura de trabalho, formando uma abundante oferta de trabalho para o

\footnotetext{
117 FERREIRA, Antonio Rafael Marchezan. Op. cit. p. 84.

118 ALFONSIN, Jacques Távora. A Força Normativa das necessidades frente ao Direito de Propriedade. Apontamento em torno dos efeitos jurídicos gerados por ocupações massivas de terra urbana e rural.In: Questões Agrárias. Julgados comentados e Pareceres. Org. Juvelino J. Strozake. SP: Editora Método, 2002, p. 16.

119 CARVALHO, Regina Maura R. de. A Expansão de Favelas na Cidade do Rio de Janeiro-Década de 80. 1996. Dissertação de Mestrado. IPPUR. RJ: 1996, p. 77/78.
} 
emergente setor da econômica urbana, provocando um aumento da demanda por habitação, num espaço urbano bastante limitado. ${ }^{120}$

Essa realidade parece não ter mudado muito apesar de esforços de governos (nas três esferas de poder) e entidades que auxiliam na questão regularização do apossamento da terra por pessoas de baixa renda como a experiência registrada por Paulo Castro no livro "O galo cantou" relativa à comunidade do Cantagalo, localizada no entorno de Copacabana, Ipanema e Leblon, zonas nobres na cidade do Rio de Janeiro. ${ }^{121}$

Em recentes matérias dos jornalistas Maria E. Alves e Rafael Galdo o jornal O Globo publicou uma terceira matéria na série de reportagens publicadas sob o título "Os Miseráveis", um retrato de nossa realidade atual, noticiando com base em pesquisas realizadas por entidades de considerável respeito que no Brasil cerca de 5,5\% da população estão na condição de miseráveis, sendo 10,94\% na Região Nordeste, 8,32\% na Região Norte, 2,85\% na Região Sudeste, 2,58\% na Região Centro-Oeste e 2,26\% na Região Sul. No Estado do Rio de Janeiro, cerca de 565.135 pessoas esperam sair da condição de miseráveis para alcançarem a condição de pobres e correspondem segundo dados do Ipea a cerca de 3,77\% da população do estado que daria para encher a cidade de Niterói que já foi capital do estado. ${ }^{122}$ Noutra matéria sob o mesmo titulo mas com enfoque na cidade do Rio de Janeiro, noticiam que favelas crescem dentro favelas, como bolsões de extrema pobreza, num total de cerca de 178.815 cariocas, cerca de 2,8\% da população, como os habitantes da comunidade chamada de Caranguejo, onde predominam barracos de madeira, casas de pau a pique na parte mais alta do PavãoPavãozinho, cerca de 780 degraus morro acima, alguns não possuindo sequer banheiro em suas moradias. ${ }^{123}$

Por outro lado o prefeito da cidade do Rio de Janeiro concede entrevista afirmando ser um péssimo exemplo outorgar concessão de uso em favela. Tal crítica surgira porque em razão das faraônicas obras que estão sendo realizadas na cidade a comunidade conhecida como Vila

120 PECHMAN, Robert Moses. A Gênese do Mercado Urbano de Terras, a Produção de Moradias e a Formação dos Subúrbios no Rio de Janeiro.1985. Dissertação de Mestrado em Ciências. UFRJ, RJ, 1985, p. 21/22.

${ }^{121}$ CASTRO. Paulo Rabello de. O galo cantou: a conquista da propriedade pelos moradores do Cantagalo. Rio de Janeiro. Record. 2011. O livro narra a experiência do Instituto Atlântico auxiliando a comunidade para obtenção de títulos de propriedade dos imóveis que ocupava. Consultem ainda ABRAMO, Pedro. "A cidade da Informalidade - o desafio das cidades latino-americanas. Rio de Janeiro: Faperj, 2003; DAMIANI, Amélia Luisa; CARLOS, Ana Fani Alessandri; SEABRA, Odette Carvalho de L. Desigualdades e Segregação da Metrópole: o Rio de Janeiro em tempo de crise. Rio de Janeiro: Revan, 2000 de Luciana Corrêa Lago.

122 O GLOBO de 31.05.2015, parte Rio, p. 28.

123 O GLOBO AMORIM, Bruno. p. 8 de 02 de jun de 2015, parte Rio. 
Autódromo (nome dado por se localizar próximo ao ex-autódromo de Jacarepaguá) estava no caminho de uma destas obras e foi necessário remover o obstáculo à continuação das obras, mas tendo em vista que alguns moradores e outros que não eram de baixa renda tinham concessão de uso de áreas publicas, o município teve que indenizá-los (indenização devida ainda que não tivesse titulo pela existência da posse dos moradores), sendo que obviamente alguns poucos exploraram atividades que não se confundem com a necessidade da moradia como hangares para helicópteros cuja a indenização a esses usuários ficou elevada, segundo noticia publicada, haja vista que 33 deles receberam indenização acima de $R \$ 1.000,000,00$ (hum milhão de reais), já tendo o município liberado para pagamento de tais indenizações cerca de $R \$ 95.000 .000,00$ (noventa e cinco milhões). ${ }^{124}$

É óbvio que esses altos valores não se destinaram aos moradores, na sua grande maioria de baixa renda. Isso se afirma, porque alguns que não saíram do local foram forçados a sair em cumprimento de decisão do juízo da 4a Vara de Fazenda Publica da Capital, gerando um confronto, uma vez que os moradores sustentam que a verba depositada não lhes permite adquirir outra moradia, tendo este confronto sido noticiado com a epígrafe: "Reintegração de posse na Vila Autódromo termina em confronto", com nove feridos entre moradores e guardas municipais. A publicação também informa que a Defensoria Publica na pessoa do Defensor Público João Helvécio que participara desde cedo das negociações mas que, devido ao insucesso dessas, logrou obter no sistema de plantão judiciário a suspenção da execução da medida de despejo, assegurando que por lei a área onde estavam os moradores resistentes foi destinada a construção de moradias. ${ }^{125}$ Na mesma semana houve uma invasão da Universidade do Estado do Rio de Janeiro - UERJ por moradores que estavam sendo despejados na chamada Favela do Metrô pelos mesmos fundamentos - obras do município, em protesto ao despejo, resultando num quebra-quebra que se tornou publico nas mídias sociais em razão de alunos darem apoio as pessoas que estariam sendo despejadas, obtendo também a Defensoria Publica a suspensão da medida por decisão da Des. Claudia Cardinalli. ${ }^{126}$

Por certo que a desapropriação lato senso é uma forma admitida pelo sistema para em nome do interesse publico ou social afastar o direito subjetivo do cidadão ao bem de sua titularidade ou posse mediante o pagamento de indenização. Contudo, como se sabe, o pagamento da indenização ocorrerá muito tempo depois da imissão na posse do bem e, de um

\footnotetext{
${ }^{124}$ Idem. O Globo. RJ, p. 11 de 15 de maio de 2015, parte Rio.

125 O Globo. RJ, p. 13 de 04 de jun de 2015, parte Rio.

126 O Globo. RJ p. 12, de 30 de maio de 2015, parte Rio.
} 
modo geral, a o valor ofertado não condiz com o valor real do direito expropriado, o que vem sendo corrigido pela jurisprudência ao determinar que o depósito que permite a imissão na posse seja realizado no valor real do bem. As pessoas de condição financeira, que em regra tem a propriedade, dispõem de um lugar para ir e quando tem noticia do ato de desapropriação já iniciam a busca de um novo lugar, mas os de baixa renda, que normalmente tem somente a posse do imóvel que lhe serve de abrigo, trabalham próximos em subempregos e não gozam da mesma facilidade, daí os conflitos coletivos pela posse da terra.

O magistrado não é um cidadão isolado como na fábula de Robinson Crusuoé. É um cidadão como outro qualquer, talhado em razão de estudos para dirimir conflitos originados no grupo social e como membro deste mesmo grupo social, deve estar antenado nas circunstancias sociais que estão à sua volta, como que numa dialética constante entre o jurídico, o social e o justo, ainda que se tenha em mente a observação de Norberto Bobbio de que "o problema fundamental em relação aos direitos do homem hoje, não é tanto o de justificá-lo, mas de protegê-lo. Trata-se de um problema não filosófico, mas politico."127

Não há dúvida assim que o valor justiça deve ser alçado, servindo o processo como instrumento para atingir tal finalidade. Veja-se a propósito a lição de Cândido Rangel Dinamarco:

"...Como a todo intérprete, incumbe ao juiz postar-se como canal de comunicação entre a carga axiológica atual da sociedade em que vive e os textos, de modo que estes fiquem iluminados pelos valores reconhecidos e assim possa transparecer a realidade da norma que contém no presente. $O$ juiz que não assuma essa postura perde a noção dos fins de sua própria atividade, a qual poderá ser exercida até de modo bem mais cômodo, mas não corresponderá às exigências de justiça". ${ }^{128}$

A este respeito colhe-se ainda em Antonio Carlos Wolkmer:

"A função jurisdicional transcende a modesta e subserviente atividade de aceder aos caprichos e à vontade do legislador (ou dos mandatários do poder), pois, como poder criador, o Juiz não se constitui em um simples técnico que mecanicamente aplica o Direito em face dos litígios reais, mas, buscando solucionar conflitos de interesse entre sujeitos individuais e coletivos de Direito, o operador jurídico aparece como uma verdadeira força de expressão social que se define pelo exercício de uma função capaz de explorar as fissuras, as antinomias e as contradições da ordem jurídica burguesa". ${ }^{129}$

${ }^{127}$ BOBBIO, Norberto. A era dos direitos. Brasília: UNB, 2000, p. 24

128 DINAMARCO. Candido Rangel. A Instrumentalidade do Processo, São Paulo: Revista dos Tribunais, 1987, p. 421/422

129 WOLKMER. Antonio Carlos. Ideologia, Estado e Direito. São Paulo: Revista dos Tribunais. 2003, p. 188. 
Pode-se tomar como parâmetro de identificação dos conflitos coletivos da posse no que diz respeito a imóveis urbanos, a noção de conflito fundiário contida no art. 3 o da Resolução Recomenda $n$ ㅇ 87 do CONCIDADES editada com objetivo de politica nacional de prevenção e mediação de conflitos fundiários urbanos. Neste sentido conflito fundiário urbano é a "disputa pela posse ou propriedade de imóvel urbano, bem como impacto de empreendimentos públicos e privados, envolvendo famílias de baixa renda ou grupos sociais vulneráveis que necessitem ou demandem a proteção do Estado na garantia do direito humano à moradia e à cidade."

Para adaptar tal noção às terras rurais é suficiente substituir a expressa cidade pelo campo, considerando que em regra o trabalhador rural, utiliza a terra para atender à necessidade de moradia do grupo familiar e para subsistência do mesmo grupo.

Neste ponto, melhor solução teria sido o legislador ter fixado de plano, a obrigatoriedade de uma audiência especial de conciliação com a participação dos órgãos indicados no $\S 1$ 으- Ministério Público (a atuação deste órgão já estava prevista pelo inc. III do art. 82 do CPC/73 com redação dada pela Lei 9.415/96) e Defensoria Publica e de órgãos dos tribunais locais que atuam na área de mediação, para se for razoável instaurar um procedimento de mediação, ${ }^{130}$ além da convocação de agentes políticos do executivo municipal, estadual e conforme o caso até Federal, mas estes últimos com objetivo de tomarem conhecimento da situação e se caso com a indicação de local apropriado ou o pagamento de auxilio financeiro à moradia (aluguel social).

A preocupação do magistrado nestes atos não deve ser com a celeridade e efetividade de sua decisão, ainda que, conforme salienta Dierle Nunes, o discurso de boa parte dos estudiosos do sistema processual se preocupe mais com as questões de sua eficiência do que com as referentes à legitimidade, não se podendo olvidar que ambas as questões são "nuances importantíssimas para a temática processual, quando se busca a aplicação do direito a partir de uma perspectiva democrática e constitucional, uma vez que ambas são complementares e interdependentes". ${ }^{131}$

Conforme o magistério de Calmon de Passos não se pode pugnar "pela efetividade do processo como se ela fosse um 'fim' bem determinado e valioso a ser alcançado". A questão

\footnotetext{
${ }^{130} \mathrm{O}$ Tribunal de Justiça do E. do Rio de Janeiro, criou em 2009 pela Res. 19 do OE alterada pelas Res. 23/2011, 16/2014 o NUPEMEC - Núcleo Permanente de Métodos Consensuais de Solução de Conflito presidido atualmente pelo Des. Cesar F. Cury.

${ }^{131}$ NUNES, Dierle. Novo enfoque para as tutelas diferenciadas no Brasil? Diferenciação procedimental a partir da diversidade de litigiosidade. Revista de Processo, SP, ano 35, vol. 184, 2010, p. 110
} 
prévia a ser definida é "qual é a função social do processo, o seu valor. Se por efetividade traduzirmos a pura e simples solução do conflito," logrando-se aparentemente pacificação social "péssimo modo de se dizer, pois em verdade e que há á sujeição do vencido mediante a chamada violência simbólica, não necessariamente o seu convencimento, que pacificaria, pouco importando a que preço e com quais consequências essa efetividade está maculada em sua origem e em sua destinação." 132

Por outro lado a tão esperada "flexibilização procedimental"133 constante do projeto do novo código de processo civil, não foi aprovada nos termos propostos mas sim timidamente. No projeto a redação do inciso $\mathrm{V}$ do art. 107 permitia ao juiz adequar as fases e atos processuais ao caso em exame:

Art. 107. O juiz dirigirá o processo conforme as disposições deste Código, incumbindo-lhe: [...] $\mathrm{V}$ - adequar as fases e os atos processuais às especificações do conflito, de modo a conferir maior efetividade à tutela do bem jurídico, respeitando sempre o contraditório e a ampla defesa." ${ }^{134}$

No entanto, o art. 139 do novo código que substitui o referido artigo 107 do projeto, no inciso VI, que guarda um pouco do sentido de flexibilização procedimental apenas permite ao juiz dilatar os prazos e alterar a ordem de produção de provas, adequando-as às necessidades do conflito, mas sempre no viés da efetividade, está objeto de crítica de Calmon de Passos acima transcrita. Neste passo vale transcrever a critica de Francis Noblat e Delton Meirelles:

"Contudo, em razão de como fora disciplinado no Anteprojeto - a Flexibilização Procedimental como "poder do juiz" - , durante o trâmite do Projeto no Senado, o instituto foi suprimido do Código após seus dispositivos serem drasticamente alterados - reduzindo-se o antes poder de adaptar o procedimento, às simples possibilidades de "aumento de prazos e a inversão da produção do meios de prova." 135

Em tema de demanda coletiva de posse a flexibilização procedimental certamente possibilitaria ao juiz diante da situação concreta, perceber com base nas regras de experiência comum e de sua experiência e preparo para o exercício da judicatura, adequar a situação

\footnotetext{
132 PASSOS, J.J. Calmon de. Cidadania e efetividade do processo. Revista Sintese de Direito Civil e Direito Processual Civil, Porto Alegre, v. 1, n. 1, set/out. 1999, p. 35.

${ }^{133}$ A respeito do tema confira-se GAJARDONI; Fernando da Fonseca. Flexibilização procedimental: um novo enfoque para o estudo do procedimento em material processual, de acordo com as recentes reformas do CPC. São Paulo: Atlas, 2008 (coleção Atlas de Processo Civil, coord. Carlos Alberto Carmona). ${ }^{134}$ BRASIL, Congresso Nacional. Senado Federal. Ato n. 379/2009. DOU, Brasilia, DF, ano CXLVI, n. 189, 02.10.2009, seção 1, p. 29

135 NOBLAT, Francis e MEIRELLES, Delton Ricardo S. De "poder do juiz" a "convenção das partes": uma análise da flexibilização procedimental na atual reforma do código de processo civil. Revista Eletronica de D. Processual, vol. XIII, p. 205.
} 
procedimental para atender sua finalidade de instrumento de realização da paz social e de justiça.

Parte da crítica de Cassio Scarpinella Bueno a despeito do velho código ainda se mantém, salvo se o operador der uma leitura de acordo com os princípios constitucionais já referidos:

\begin{abstract}
"É bastante comum na prática do foro que as "ações possessórias" sejam propostas contra Movimentos Sociais que, como tais, invadem ou anunciam invasões de terras de norte a sul, leste a oeste do país. O que cumpre destacar nessa sede a respeito da questão é que o sistema codificado não foi pensado e também não, pelo menos até o momento, modificado para tratar de tais situações. O Código, não por defeito seu, mas por representar uma época, uma ideologia e seu respectivos valores, não cuida de situações coletivas mas, apenas e tão somente individuais." 136
\end{abstract}

De imediato, em especial porque não há, em regra, para o titular do direito de propriedade prejuízo algum no retardamento da solução judicial, uma vez, como já salientado, que a instaurar, como permite o inciso $V$ do art. 139 parte final, procedimento de mediação, aproveitando-se da dicção contida no dispositivo: preferencialmente.

Para tanto a atuação da Defensoria Publica e demais órgãos que cuidam das politicas publicas de habitação deverão ter participação efetiva. O primeiro, sob pena de nulidade dos atos processuais praticados sem sua intervenção e os segundos para viabilizarem a celebração de ajustes entre as partes, quando for necessária a retirada das famílias para outro local.

Não se chegando a bom termo nos procedimentos de conciliação e mediação, então deverá o magistrado examinar os aspectos do direito material e processual envolvidos na situação como acima assinalado: qual direito merece a tutela garantida pela constituição a posse ou a propriedade? Qual deles cumpre ou visa cumprir a função social estabelecida na constituição? Para, então, só após decidir e certamente se observados estes parâmetros sua decisão, superada a questão social e politica, atenderá aos fins do processo e da justiça.

\title{
CONCLUSÃO
}

A ocupação histórica irregular do solo brasileiro aliada a insuficientes políticas públicas de habitação resultaram em um problema de moradia no Brasil que resultou em ocupação

\footnotetext{
136 BUENO. Cassio Scarpinella. Curso Sistematizado de Direito Processual Civil, vol. 2, tomo II, 3a ed. São Paulo: Saraiva, 2014, p. 80.
} 
irregular em áreas não almejadas pelo mercado e a necessidade da busca pelo reconhecimento dessas posses e a respectiva regularização fundiária.

Inegável, que uma vez que tais posses ocorrem em áreas de proteção ambiental há uma tensão com direito à moradia, além do inevitável conflito com a propriedade formal que conduzem ao deslocamento do debate das políticas públicas para o âmbito do controle pelo Poder Judiciário.

Neste sentido, o novo Código de Processo Civil traz importante instrumento no que tange ao controle judicial da regularização fundiária de áreas ambientais forma a garantir a proteção do direito humano fundamental social à moradia mediante o reconhecimento e proteção as referidas posses.

\section{REFERÊNCIAS}

ABRAMO, Pedro. "A cidade da Informalidade - o desafio das cidades latino-americanas. Rio de Janeiro: Faperj, 2003.

ALEXY, Robert. Teoria dos Direitos Fundamentais. Malheiros: São Paulo, 2008.

ALFONSIN, Jacques Távora. A Força Normativa das necessidades frente ao Direito de Propriedade. Apontamento em torno dos efeitos jurídicos gerados por ocupações massivas de terra urbana e rural.In: Questões Agrárias. Julgados comentados e Pareceres. Org. Juvelino J. Strozake. SP: Editora Método, 2002,

ALMEIDA, Francisco de P. Lacerda de. Direito das cousas. Rio de janeiro: Ribeiro dos Santos, 1908.

ALVES, José Carlos M.. Direito Romano. 9a edição. vol I. Rio de Janeiro: Forense, 1995

AMARAL, Francisco. Direito Civil. Introdução. Rio de Janeiro: Forense, 1991. 
ANDRADE, Manuel A. Domingues. Teoria Geral da Relação Jurídica. Vol 1. Coimbra: Livraria Almedina, 1983.

Ensaio sobre a Teoria da Interpretação das Leis. 3a. ed., Coimbra: Armênio Amado,

ARONNE, Ricardo. Propriedade e Domínio. Reexame Sistemático das Noções Nucleares de Direitos Reais. Rio de Janeiro: Renovar, 1999.

ARRUDA ALVIM. Breves Anotações para uma Teoria Geral dos Direitos Reais, in Posse e Propriedade. São Paulo: Saraiva Ed., 1987.

BALDEZ, Miguel Lanzellotti. Solo urbano: Propostas para a Constituinte. Rio de Janeiro: Apoio Juridico Popular, 1986.

BARAT, Josef. Problemas Institucionais do Planejamento Urbano. in: KACOWICZ, Mateus. Desenvolvimento e Política Urbana. Rio de Janeiro: IBAM, 1976

BASTOS, Celso R. A função social como limite constitucional ao D. de Propriedade. Revista de Dir. Constitucional e Ciência Política. no. 6, vol. 4, 1988.

MARTINS, Ives Gandra. Comentários à Constituição do Brasil. São Paulo: Saraiva Ed., 1989.

BENATTI, José Helder. O meio ambiente e os bens ambientais. In: RIOS, Aurélio Virgílio Veiga; IRIGARAY, Carlos Teodoro Hugueney. O direito e o desenvolvimento sustentável. São Paulo Petrópolis: Instituto Internacional de Educação do Brasil, 2005.

BENJAMIN, Antonio Herman V. (Coord.). Dano ambiental: prevenção, reparação e repressão. SãoPaulo: Revista dos Tribunais, 1993,

BESSONE, Darcy. Direitos Reais. Rio de Janeiro: Saraiva, 1988.

BEVILAQUA, Clovis. Direito das Coisas. 4a. Ed., vol. I. Forense. 1956.

O Conceito de Propriedade. Rev. de Direito Público. Vol. II. Freitas Bastos Ed., 1940. Teoria Geral, 2a. ed., Rio de Janeiro: Liv. Francisco Alves, 1929, 
BEZERRA, Raimundo Falcão. A função social da propriedade. São Paulo: RDA, vol. 55/56,

BONDUKI. Nabil; KOURY, Ana Paula. Das Reformas de Base ao BNH: As Propostas do Seminário de Reforma Urbana. XII Encontro da Associação Nacional de Pós-Graduação e Pesquisa em Planejamento Urbano e Regional, 21 a 25 de Maio de 2007, Belém, Pará, Rio de Janeiro.

BRASILEIRO, Ana Maria. A Cidade: Aspectos Políticos in: KACOWICZ, Mateus. Desenvolvimento e Política Urbana. Rio de Janeiro: Instituto Brasileiro de Administração Municipal, 1976.

BUENO. Cassio Scarpinella. Curso Sistematizado de Direito Processual Civil, vol. 2, tomo II, 3a ed. São Paulo: Saraiva, 2014.

CARVALHO, Regina Maura R. de. A Expansão de Favelas na Cidade do Rio de Janeiro-Década de 80. 1996. Dissertação de Mestrado. IPPUR. RJ: 1996.

CARRASCO, Andrea de Menezes. Jurisdicização e Promoção da Função Socioambiental da Propriedade Urbana in: MOTA, Maurício; TORRES, Marcos Alcino. Transformações do Direito de Propriedade Privada. Rio de Janeiro: Ed. Elsevier, 2009.

CARRERA, Francisco. Cidade Sustentável: Utopia ou Realidade? Rio de Janeiro: Lumen Juris, 2005.

CASTRO. Paulo Rabello de. O galo cantou: a conquista da propriedade pelos moradores do Cantagalo. Rio de Janeiro. Record. 2011.

CAVEDON, Fernanda de Salles. Função social e ambiental da propriedade. Florianópolis: Visualbooks, 2003.

COULANGES, Fustel. A cidade antiga: estudos sobre o culto, o direito, as instituições da Grécia e de Roma. Trad. Fernando de Aguiar, 9ạ ed. Lisboa: Livraria Clássica Editora, 1957. 
COUTINHO, Ronaldo do Livramento. Direito Ambiental das Cidades: Questões TeóricoMetodológicas in: COUTINHO, Ronaldo; ROCCO, Rogério (Org). O Direito Ambiental das Cidades. 2 ed. rev. Atual e ampla. Rio de Janeiro: Lumen Juris, 2009.

DAMIANI, Amélia Luisa; CARLOS, Ana Fani Alessandri; SEABRA, Odette Carvalho de L. Desigualdades e Segregação da Metrópole: o Rio de Janeiro em tempo de crise. Rio de Janeiro: Revan, 2000.

DEAN, Warren. A ferro e fogo: a história e a devastação da Mata Atlântica Brasileira. São Paulo: Companhia das Letras, 1996.

DIDIER JUNIOR, Freddie. A função social da propriedade e a tutela processual da posse. Revista de Processo 2008 - Repro 161.

DINAMARCO. Candido Rangel. A Instrumentalidade do Processo, São Paulo: Revista dos Tribunais, 1987.

DUARTE, Marise Costa de Souza. Meio Ambiente e Moradia: Direitos Fundamentais e Espaços Especiais na Cidade. Curitiba: Juruá, 2012.

FACHIN, Luiz E. A Função Social da Posse e a Propriedade Contemporânea. Porto Alegre: Sergio A Fabris Editor, 1988.

O estatuto constitucional da proteção possessória. Leituras complementares de Direito Civil. Cristiano C. de Farias (coord). São Paulo: Jus Podim, 2007.

FERREIRA, Antonio Rafael Marchezan. Tutela possessória e a remoção forçada de grupos vulneráveis e famílias de baixa renda, in Revista Eletrônica de D. Proc. Civil, FUKASSAWA, Fernando. Regularização fundiária urbana. São Paulo, Saraiva, 2013.

FULGÊNGIO, Tito. Direito de vizinhança. Rio de Janeiro: Forense, 1959.

GASSEN, Valcir. A Natureza Histórica da Instituição do Direito de Propriedade. In Fundamentos de História do Direito, Org. Antonio Carlos Wolkmer, 2a ed. Belo Horizonte: Del Rey, 2006. 
GOMES, Orlando. Direitos reais. 19a ed. Rio de Janeiro: Ed. Forense, 2004.

GONÇALVES, Luiz da Cunha. Da propriedade e da posse. São Paulo: Edições Ática, 1952

HARVEY, David. A Justiça Social e a Cidade. São Paulo: Hucitec, 1980.

HOLANDA, Sérgio Buarque de. As Raízes do Brasil. São Paulo: Companhia das Letras,. 2008.

HUMBERT, Georges Louis Hage. Direito Urbanístico e Função Socioambiental da Propriedade Imóvel Urbana. Belo Horizonte: Fórum, 2009.

KICH, Bruno C. A Propriedade na Ordem Jurídica, Econômica e Ideológica. Porto Alegre: Sérgio Fabris, 2004.

LACERDA, M.Linhares de. Tratado das Terras do Brasil. Vol 1. Rio de Janeiro: Editora Alba Ltda, 1960.

LEAL, Rogério Gesta. Direito Urbanístico. Porto Alegre: Renovar, 2003.

LEMOS, Patrícia Faga Iglecias. Meio ambiente e responsabilidade civil do proprietário: análise do nexo causal. São Paulo: Revista dos Tribunais, 2008

LIRA, Ricardo Pereira. Elementos de Direito Urbanístico. Rio de Janeiro: Renovar, 1997.

LOPES, M M. de Serpa. Curso de Direito Civil. Direito das Coisas: Princípios Gerais, Posse, Dominio e Propriedade Imóvel. 2a ed., vol. VI, São Paulo/Rio de Janeiro: Livraria Freitas Bastos, 1962.

LOPES, Miguel M. de S. Curso de Direito Civil. V. VI, 2a ed. Rio de Janeiro-São Paulo: Livraria Freitas Bastos S/A, 1962.

MARICATO, Erminia. Habitação e Cidade. 6 ed. São Paulo: Atual, 1997. 
Metrópole na Periferia do Capitalismo: Ilegalidade, Desigualdade E Violência. São Paulo: Editora Hucitec, 1996.

Cidades: Alternativas para a Crise Urbana. Petrópolis: Vozes, 2001.

MENDONÇA, Marcos Carneiro de. Raízes da Formação Administrativa do Brasil. Foral de Duarte Coelho. Rio de Janeiro: IHGB/Conselho Federal de Cultura, 1972, tomo I, regimento III-B.

MIRANDA, Francisco Cavalcanti Pontes de. Tratado de Direito Privado. Tomo II. Bens. Rio de Janeiro: Editor Borsoi, 1954.

MIRRA, Álvaro Luiz. Princípios Fundamentais do Direito Ambiental. In: Cidadania Coletiva. Florianópolis: Paralelo 27, 1996.

MONTEIRO, Washington de Barros, Curso de Direito Civil. vol. 3. 37a ed. São Paulo: Saraiva, 2003.

MOREIRA, Mariana. A História do Estatuto da Cidade in: DALLARI, Adilson Abreu;

MOTA, Mauricio Jorge Pereira da. O conceito de natureza e a reparação das externalidades ambientais negativas. Revista eletrônica da Faculdade de Direito de Campos, Campos dos Goytacazes, RJ, v. 2, n. 2, abr. 2007

TORRES, Marcos Alcino (Coord). In: A Função Social da Posse no Código Civil in: MOTA, Maurício; TORRES, Marcos Alcino (Org.). Transformações do Direito de Propriedade Privada. Rio de Janeiro: Elsiever, 2009.

NOBLAT, Francis e MEIRELLES, Delton Ricardo S. De "poder do juiz" a "convenção das partes": uma análise da flexibilização procedimental na atual reforma do código de processo civil. Revista Eletronica de D. Processual, vol. XIII.

NUNES, Dierle. Novo enfoque para as tutelas diferenciadas no Brasil? Diferenciação procedimental a partir da diversidade de litigiosidade. Revista de Processo, SP, ano 35, vol. 184, 2010. 
PASSOS, J.J. Calmon de. Cidadania e efetividade do processo. Revista Sintese de Direito Civil e Direito Processual Civil, Porto Alegre, v. 1, n. 1, set/out. 1999.

PENA-VEJA, Alfredo. O despertar ecológico: Edgar Morin e a ecologia complexa. 2. ed. Rio de Janeiro: Garamond, 2005, Perfis do direito civil: introdução ao direito civil constitucional. 3. ed. Rio de Janeiro: Renovar, 2007,

PEREIRA, Caio M. da S. Instituições de Direito Civil. v. IV, Forense, RJ, 2003,

PEREIRA, Lafayette R. Direito das Coisas. Vol I. Brasilia: Senado Federal, 2004.

PEREIRA, Marlene de Paula. Releituras da Teoria Possessória: Da Posse como Projeção do Direito de Propriedade a um Instituto Autônomo e Transformador da Realidade Social in: MOTA, Maurício; TORRES, Marcos Alcino. Transformações do Direito de Propriedade Privada. Rio de Janeiro: Ed. Elsevier, 2009.

PEREIRA, Virgílio de Sá. Direito das Coisas. vol. VIII. São Paulo: Jacintho Ribeiro dos Santos, 1924.

RANGEL, Paulo Castro. Concentração, programação e Direito do Ambiente. Coimbra: Coimbra Editora, 1994.

REIS, Jane. Interpretação Constitucional e Direitos Fundamentais. Rio de Janeiro: Renovar, 2006.

RIOS, Arthur. Regularização Fundiária Urbana. Curitiba: Juruá, 2012.

RIZZARDO, Arnaldo. Direito das Coisas. 2aㅡ ed. Rio de Janeiro: Ed. Forense, 2006.

RODRIGUES. Manuel. A Posse. Estudo de Direito Civil Português, Almedina, Coimbra, 1996.

RODRIGUES, Silvio. Direito Civil. Direito das Coisas. 28 ed: Edit. Saraiva, vol. 5, 2003,

RUGGIERO, Roberto de. Instituições do Direito Civil. Vol. 2. Sâo Paulo: Saraiva,1972.

Revista de Direito da Cidade, vol. 10, no 4. ISSN 2317-7721 pp. 2315-2368 
SALE JUNIOR, Nélson. Novas Perspectivas do Direito Urbanístico Brasileiro: Ordenamento Constitucional da Política Urbana. Aplicação e Eficácia do Plano Diretor. Porto Alegre: Sergio Antonio Fabris Editor, 1997.

SILVA, José Afonso da. Direito Urbanístico Brasileiro. 7 ed. São Paulo: Malheiros, 2012.

SILVA, José Robson da. Paradigma biocêntrico: do patrimônio privado ao patrimônio ambiental. Rio de Janeiro: Renovar, 2002.

SOLON, Ari Marcelo. A função do conceito de direito subjetivo de propriedade. Dissertação de Mestrado apresentado na USP. São Paulo, 1987,

SOUZA, Sérgio Iglesia Nundes de. Direito à Moradia e de Habitação. São Paulo: Revista dos Tribunais, 2008.

STEIGLEDER, Annelise Monteiro. Responsabilidade civil ambiental: as dimensões do dano ambiental no direito brasileiro. Porto Alegre: Livraria do Advogado, 2004,

THEODORO JUNIOR, Humberto. Posse e Propriedade. São Paulo: Livraria e Editora Universitária de Direito Ltda, 1988.

TEPEDINO, Gustavo. A Tutela da Propriedade Privada na Ordem Constitucional. Revista da Faculdade de Direito da UERJ, vol. 1, 1993.

A Nova Propriedade. RF, no 306, 1989

TORRES, Marcos Alcino de Azevedo. A propriedade e a posse: um confronto em torno da função social. Rio de Janeiro: Lumen Juris, 2007.

A função social da posse no Código Civil. TORRES, M. A. de A. e Mota, Mauricio J. P., in Transformações do Direito de Propriedade Privada. Rio de Janeiro: Ed. Elsevier, 2009, Impacto das Novas Idéias na Dogmática do Direito de Propriedade in: TORRES, M. A. de A. e Mota, Mauricio J. P., in Transformações do Direito de Propriedade Privada. Rio de Janeiro: Ed. Elsevier, 2009, 
VARELA, Laura Beck. Das propriedades à propriedade: construção de um direito. In: A reconstrução do Direito Privado. Org. Judith Martins-Costa. São Paulo: RT, 2002.

VIANNA JÚNIOR, Hélio. A Estrutura Interna da Cidade in: KACOWICZ, Mateus. Desenvolvimento e Política Urbana. Rio de Janeiro: IBAM, 1976.

VIANNA, Oliveira. Populações Meridionais do Brasil. Brasília: Senado Federal, 2005.

VILLEY, Michel. Estúdios em torno da la nocion de Derecho Subjetivo. Valparaiso: Universidad Católica de Valparaiso, 1976.

ZAVASCKI, Teori Albino. A tutela da posse na Constituição e no projeto do novo Código Civil. In: MARTINS-COSTA, Judith (Coord.). A reconstrução do Direito Privado. São Paulo: Revista dos Tribunais, 2002,

Trabalho enviado em 27 de janeiro de 2018

Aceito em 10 de maio de 2018 